ARTICLE

Received 30 Aug 2016 | Accepted 21 Mar 2017 | Published 22 May 2017

DOI: $10.1038 /$ ncomms15338 OPEN

\title{
Notch-mediated conversion of activated T cells into stem cell memory-like T cells for adoptive immunotherapy
}

Taisuke Kondo', Rimpei Morita1, Yuumi Okuzono², Hiroko Nakatsukasa1, Takashi Sekiya', Shunsuke Chikuma1, Takashi Shichita ${ }^{1}$, Mitsuhiro Kanamori ${ }^{1}$, Masato Kubo ${ }^{3,4}$, Keiko Koga ${ }^{2}$, Takahiro Miyazaki ${ }^{2}$, Yoshiaki Kassai ${ }^{2}$ \& Akihiko Yoshimura ${ }^{1}$

Adoptive T-cell immunotherapy is a promising approach to cancer therapy. Stem cell memory $T\left(T_{S C M}\right)$ cells have been proposed as a class of long-lived and highly proliferative memory $\mathrm{T}$ cells. CD8 ${ }^{+} \mathrm{T}_{\mathrm{SCM}}$ cells can be generated in vitro from naive $\mathrm{CD} 8{ }^{+} \mathrm{T}$ cells via $\mathrm{Wht}$ signalling; however, methods do not yet exist for inducing $\mathrm{T}_{\mathrm{SCM}}$ cells from activated or memory $T$ cells. Here, we show a strategy for generating $\mathrm{T}_{\mathrm{SCM}}$-like cells in vitro ( $\mathrm{i}_{\mathrm{SCM}}$ cells) from activated $\mathrm{CD}_{4}{ }^{+}$and $\mathrm{CD} 8{ }^{+}{ }^{+}$cells in mice and humans by coculturing with stromal cells that express a Notch ligand. $\mathrm{iT}_{\mathrm{SCM}}$ cells lose PD-1 and CTLA-4 expression, and produce a large number of tumour-specific effector cells after restimulation. This method could therefore be used to generate antigen-specific effector T cells for adoptive immunotherapy.

\footnotetext{
${ }^{1}$ Department of Microbiology and Immunology, Keio University School of Medicine, 35 Shinanomachi, Shinjuku-ku, Tokyo 160-8582, Japan. ${ }^{2}$ Inflammation Drug Discovery Unit, Pharmaceutical Research Division, Takeda Pharmaceutical Company Limited, 26-1 Muraoka-Higashi 2-chome, Fujisawa-shi, Kanagawa 251-8555, Japan. ${ }^{3}$ Division of Molecular Pathology, Research Institute for Biomedical Science, Tokyo University of Science, 2641 Yamazaki, Noda-shi, Chiba 278-8510, Japan. ${ }^{4}$ Laboratory for Cytokine Regulation, RIKEN Center for Integrative Medical Sciences (IMS), RIKEN Yokohama Institute, 1-7-22 Suehiro-cho, Tsurumi-ku, Yokohama City, Kanagawa 230-0045, Japan. Correspondence and requests for materials should be addressed to A.Y. (email: yoshimura@a6.keio.jp).
} 
A doptive T-cell transfer to treat cancer has been applied in clinical settings, but the effects have been limited because activated $\mathrm{T}$ cells are short-lived and easily lose their functionality 1,2 . Indeed, acquired tumour-specific $\mathrm{T}$ cells are often already exhausted in tumour microenvironments, and the enhancement of effector function in vitro paradoxically attenuates the in vivo antitumour efficacy of transferred $\mathrm{T}$ cells $^{3,4}$. To overcome these obstacles, rejuvenated functional cytotoxic $\mathrm{T}$ lymphocytes (CTLs) can be generated from induced pluripotent stem (iPS) cells derived from antigen-specific $\mathrm{T}$ cells ${ }^{5,6}$, a strategy that provides an unlimited supply of antigen-specific CTLs. However, T cell receptor (TCR) repertoires are often restricted in the process of iPS cell generation, which may result in the failure to react to a broad variety of tumour-associated antigens (TAAs). Transplantation of multiple TAA-reactive and expandable $T$ cells may be efficacious against antigenic-drifted tumour cells that evade destruction by CTLs.

$\mathrm{T}$ cell populations have been classified by several surface markers and distinguished by their functions and residency, along with their effector cytokine production. Effector memory $\mathrm{T}\left(\mathrm{T}_{\mathrm{EM}}\right)$ cells and central memory $\mathrm{T}\left(\mathrm{T}_{\mathrm{CM}}\right)$ cells circulate in the blood and target the secondary lymphoid tissues ${ }^{7}$. Resident memory $\mathrm{T}\left(\mathrm{T}_{\mathrm{RM}}\right)$ cells remain at local sites to respond immediately to secondary infection. These cells can rapidly produce multiple functional molecules after restimulation to control the invasion and spread of pathogens. However, $\mathrm{T}_{\mathrm{EM}}$ and $\mathrm{T}_{\mathrm{RM}}$ cells have a limited potential for population expansion, and tend to become terminally differentiated and subsequently exhausted. Naive $\mathrm{T}$ cells, which have not been exposed to antigens, resist terminal differentiation and exhaustion when compared with memory $\mathrm{T}$ cells, and maintain strong proliferative potential after antigen stimulation. Therefore, compared with other subsets, naive $\mathrm{T}$ cells may be superior for adoptive immunotherapy ${ }^{8}$. However, the number of naive $\mathrm{T}$ cells that are specific for any given antigen is very low compared with memory $\mathrm{T}$ cells. Thus, antigen-specific memory $\mathrm{T}$ cells that have naive-like phenotypes are ideal for adoptive $\mathrm{T}$ cell therapy.

$\mathrm{T}$ cell subsets were originally classified into naive, effector and several memory cell populations ${ }^{9}$. However, the classification does not fully represent the contribution of $\mathrm{T}$ cell populations in infectious diseases, cancer, and disorders of ageing, and technical advances have revealed the existence of previously unknown $\mathrm{T}$ cell subsets. For example, memory stem cells $\left(\mathrm{T}_{\mathrm{SCM}}\right)$ and memory cells with naive phenotypes $\left(\mathrm{T}_{\mathrm{MNP}}\right)$ have been detected in $\mathrm{T}$ cell populations previously characterized as being naive ${ }^{10,11}$. Both $\mathrm{T}_{\mathrm{SCM}}$ and $\mathrm{T}_{\mathrm{MNP}}$ cells, which express naive $\mathrm{T}$ cell markers $\left(\mathrm{CD} 45 \mathrm{RA}^{+} \mathrm{CD} 45 \mathrm{RO}^{-} \mathrm{CCR} 7{ }^{+} \mathrm{CD} 6 \mathrm{~L}^{+}\right)$, respond rapidly to antigens, express multiple effector molecules and produce memory and effector cells. Notably, these subsets have greater proliferative potential than naive cells.

The method by which $\mathrm{T}_{\mathrm{SCM}}$ cells are generated both in vivo and in vitro is not well established. Gattinoni et al. found that mouse and human $\mathrm{CD} 8{ }^{+} \mathrm{T}_{\mathrm{SCM}}$ cells can be generated effectively in vitro from naive $\mathrm{CD} 8^{+} \mathrm{T}$ cells by stimulating the TCR in the presence of Wnt3A or inhibitors of glycogen synthase kinase- $3 \beta$ $(\text { GSK- } 3 \beta)^{10,12}$. We confirmed that a GSK-3 $\beta$ inhibitor generated CD8 ${ }^{+} \mathrm{T}_{\mathrm{SCM}}$ cells from naive $\mathrm{T}$ cells in vitro, yet this method failed to generate $\mathrm{CD} 4^{+}$and $\mathrm{CD} 8{ }^{+} \mathrm{T}_{\mathrm{SCM}}$ cells from activated $\mathrm{T}$ cells. While verifying the effects of signalling molecules on $\mathrm{T}$ cells, we discovered that Notch signalling converts activated $\mathrm{T}$ cells into $\mathrm{T}_{\mathrm{SCM}^{-}}$-like cells (called ' $\mathrm{iT}_{\mathrm{SCM}}$ ' cells) in mice and humans. These i $\mathrm{T}_{\mathrm{SCM}}$ cells are generated by coculturing of activated $\mathrm{T}$ cells with Notch ligand-expressing stromal cells. $\mathrm{iT}_{\mathrm{SCM}}$ cells respond to antigen restimulation with greater expanding potential than other $\mathrm{T}$ cell subsets. $\mathrm{iT}_{\mathrm{SCM}}$ cells also have a long-lived and self-renewing potential, are resistant to cell cycle arrest and apoptosis after TCR stimulation, and demonstrate great antitumour activity. Therefore, $\mathrm{iT}_{\mathrm{SCM}}$ cells may be used as an innovative strategy in the adoptive immunotherapy of cancer and infectious diseases.

\section{Results}

Induction of naive-like $\mathrm{T}$ cells from activated $\mathrm{CD} 4{ }^{+} \mathrm{T}$ cells. The GSK-3 $\beta$ inhibitor TWS119 has been used for $\mathrm{T}_{\mathrm{SCM}}$ cell generation from naive $\mathrm{T}$ cells by arresting effector $\mathrm{T}$ cell differentiation ${ }^{13,14}$. This method successfully worked for naive $\mathrm{CD} 8^{+}$ $\mathrm{T}$ cells, but it was not effective for naive and differentiated CD4 ${ }^{+}$ $\mathrm{T}$ cells (Supplementary Fig. 1a-c). Therefore, we explored the signalling molecules that induce $\mathrm{CD} 4{ }^{+} \mathrm{T}_{\mathrm{SCM}}$ cells, and we subsequently discovered that Notch signalling converted activated $\mathrm{CD}^{+} \mathrm{T}$ cells into $\mathrm{T}_{\mathrm{SCM}}$-like cells, which expressed naive markers, $\mathrm{CD} 44^{\mathrm{lo}} \mathrm{CD} 62 \mathrm{~L}^{\mathrm{hi}}$. Notch signalling is important not only for $\mathrm{T}$ cell differentiation and function ${ }^{15-17}$, but also for the maintenance of memory $\mathrm{T}$ cells in vivo ${ }^{18}$. We found that both $\mathrm{CD} 4{ }^{+}$and $\mathrm{CD} 8{ }^{+} \mathrm{T}$ cells came to express mainly Notch 1 and Notch2, when they were activated under various culture conditions (Supplementary Fig. 2a,b). The method we have established is described as follows. First, to obtain antigenspecific, activated $\mathrm{CD} 4{ }^{+} \mathrm{T}$ cells, OVA-specific CD $44^{\mathrm{lo}} \mathrm{CD} 62 \mathrm{~L}^{\mathrm{hi}}$ naive $\mathrm{CD} 4^{+} \mathrm{T}$ cells were isolated from OT-II mice, and then cocultured with OVA peptide-pulsed dendritic cells (OVA-DCs). Four days later, $\mathrm{CD} 44^{\text {hi }}$ activated $\mathrm{T}$ cells, which showed memory precursor cell phenotypes $\left(\mathrm{CD} 127^{+} \mathrm{KLRG}^{-}\right.$) (Supplementary Fig. 2c), were isolated by FACS and then cocultured with Notch ligand Delta-like 1-expressing murine bone marrow stromal cells (OP9-DL1 cells) or OP9 cells in the presence of IL-7 and anti-IFN- $\gamma$ neutralizing antibody (Ab) for up to 12 days (Fig. 1a). When we used anti-CD3/CD28 antibodies to activate wild-type $\mathrm{CD} 4^{+}$Tcells in vitro, $\mathrm{CD} 44^{\mathrm{lo}} \mathrm{CD} 62 \mathrm{~L}^{\mathrm{hi}}$ fraction appeared 4 days after coculture with OP9-DL1 feeder cells.

Coculturing with OP9-DL1 cells significantly induced the expression of multiple Notch target genes (Myc, Deltex1, Hes 1$)$ in the $\mathrm{CD}^{+} \mathrm{T}$ cells (Supplementary Fig. 2d). Consequently, coculturing with OP9-DL1 cells in the presence of both IL-7 and anti-IFN- $\gamma \mathrm{Ab}$ let $\mathrm{CD} 4^{+} \mathrm{T}$ cells survive and expand, and $20-30 \%$ of the CD4 $4^{+}$T cells cocultured with OP9-DL1 cells downregulated CD44 expression, resulting in phenotypically naive $\mathrm{T}$ cells, which we called induced- $\mathrm{T}_{\mathrm{SCM}}\left(\mathrm{iT}_{\mathrm{SCM}}\right.$ ) cells and $40-60 \%$ of the $\mathrm{CD} 4^{+} \mathrm{T}$ cells were $\mathrm{CD} 44^{\mathrm{hi}} \mathrm{CD} 62 \mathrm{~L}^{\mathrm{hi}} \mathrm{T}$ cells, which we called induced- $\mathrm{T}_{\mathrm{CM}}\left(\mathrm{iT}_{\mathrm{CM}}\right)$ cells (Fig. $\left.1 \mathrm{~b}\right) . \mathrm{CD} 44^{\mathrm{hi}} \mathrm{CD} 62 \mathrm{~L}^{\mathrm{lo}}$ naive-like iT $\mathrm{SCM}_{\mathrm{SC}}$ cells were not induced by the coculture with $\mathrm{OP} 9$ cells not expressing DL1 (Fig. 1b). Both IL-7 and anti-IFN- $\gamma$ Ab were essential to obtain fine proliferation of $\mathrm{T}$ cells on the OP9-DL1 feeder cells (Supplementary Fig. 2e). We obtained $4-5 \times 10^{6}$ of $\mathrm{iT}_{\mathrm{SCM}}$ and $8-9 \times 10^{6}$ of the $\mathrm{iT}_{\mathrm{CM}}$ cells from $1 \times 10^{6}$ of the naive $\mathrm{T}$ cells, indicating that a portion of the activated $\mathrm{CD} 4{ }^{+} \mathrm{T}$ cells proliferated and converted into $\mathrm{CD} 44^{\mathrm{lo}} \mathrm{CD} 62 \mathrm{~L}^{\mathrm{hi}}$ $\mathrm{iT}_{\mathrm{SCM}}$ cells (Fig. 1c). Activated $\mathrm{CD} 4^{+} \mathrm{T}$ cells did not proliferate well during the coculture with OP9 cells, thus the number of $\mathrm{CD}_{2} \mathrm{~L}^{+}$cells did not increase during coculture (Fig.1c). Thus, Notch signalling is necessary not only for induction of $\mathrm{iT}_{\mathrm{SCM}}$ cells but also for proliferation and/or survival of $\mathrm{T}$ cells.

To show an essential role of Notch signalling in $\mathrm{iT}_{\mathrm{SCM}}$ induction, the Notch inhibitor, DAPT was included in the coculture. Treatment with DAPT significantly suppressed the induction of $\mathrm{CD} 44^{\mathrm{lo}} \mathrm{CD} 62 \mathrm{~L}^{\mathrm{hi}} \mathrm{iT}_{\mathrm{SCM}}$ cells (Fig. 1d). Conversely, a Notch ligand-Fc protein (mDLL1-Fc) and overexpression of the Notch intracellular domain strongly induced $\mathrm{CD} 44^{10} \mathrm{CD} 62 \mathrm{~L}^{\mathrm{hi}}$ $\mathrm{iT}_{\mathrm{SCM}}$ cells (Fig. 1e,f). To observe the induction of $\mathrm{iT}_{\mathrm{SCM}}$ cells from activated $\mathrm{CD} 4{ }^{+} \mathrm{T}$ cells at a single cell level, we first sorted IFN- $\gamma$-highly producing activated $\mathrm{CD} 4{ }^{+} \mathrm{T}$ cells (Supplementary 
a

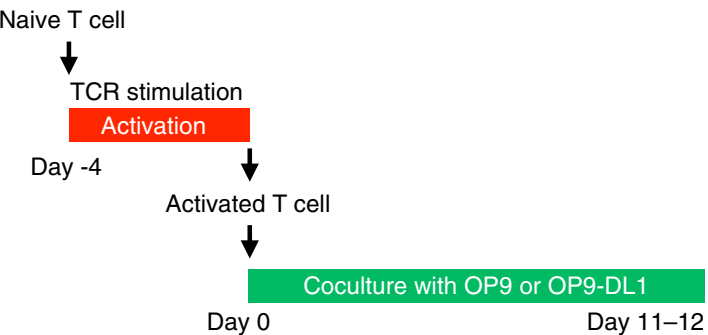

C
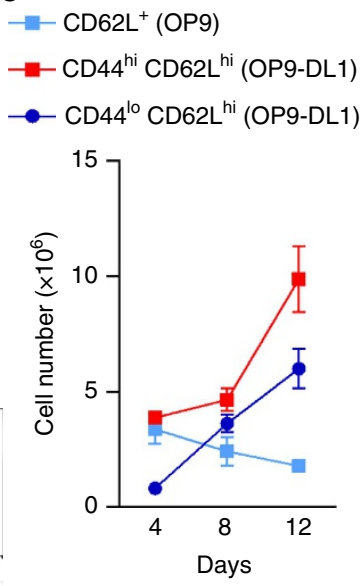

b
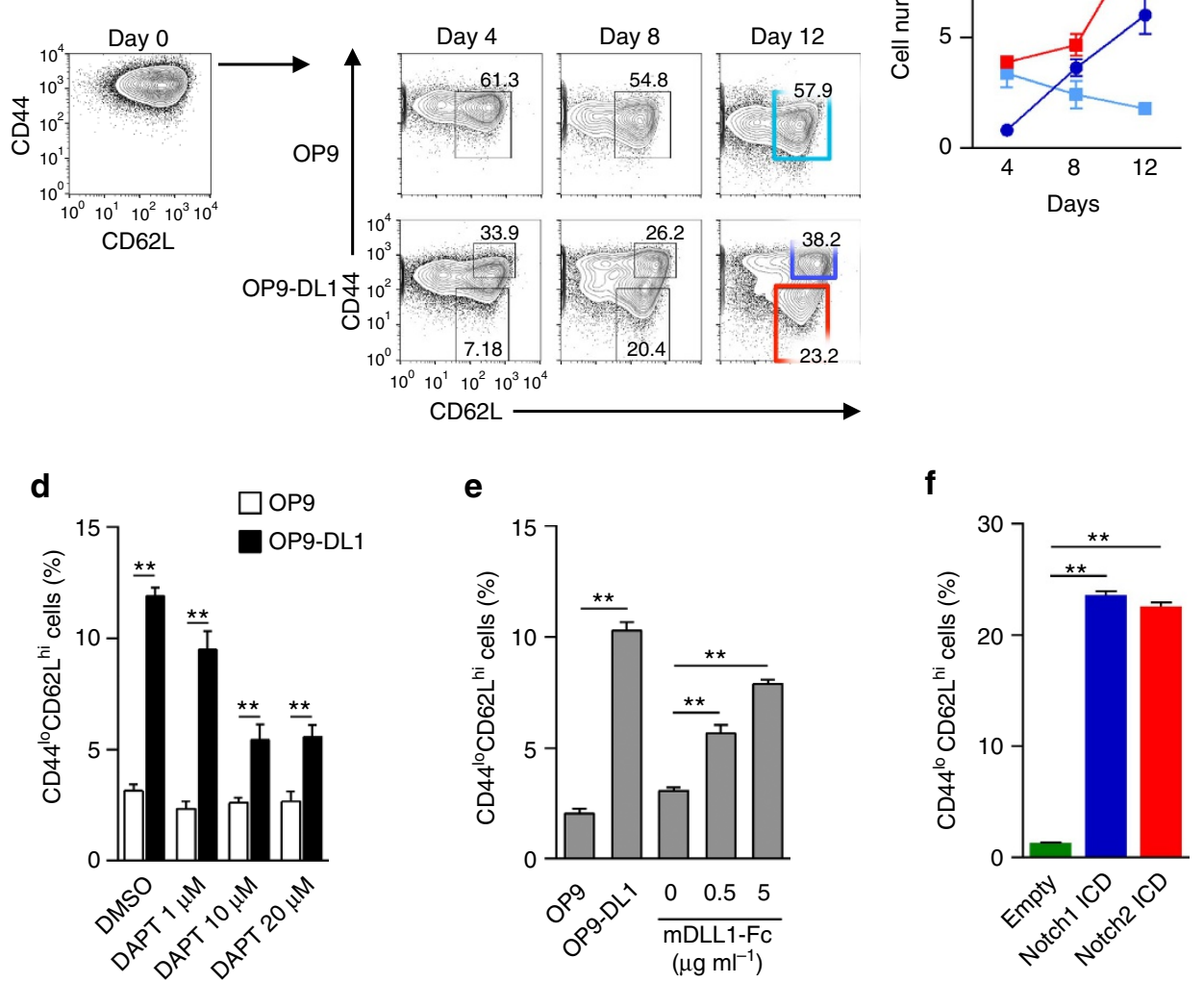

e

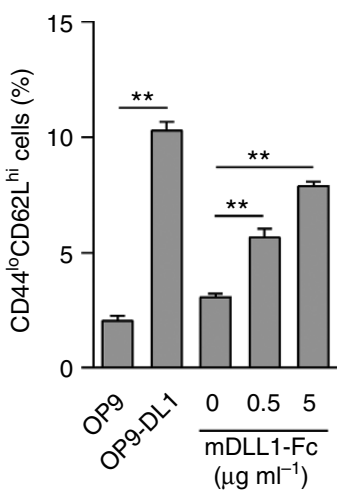

f

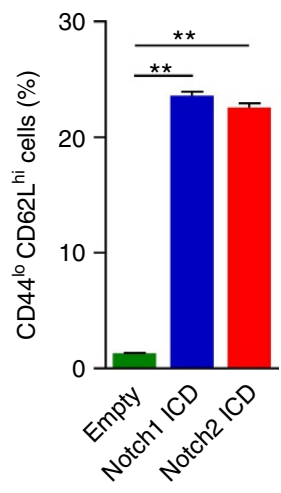

Figure 1 | Notch signalling generates CD4 ${ }^{+} \mathbf{i} \mathbf{T}_{\mathbf{S C M}}$ cells. (a) Scheme of the experimental design for the OP9 or OP9-DL1 cell coculture system. (b) CD44 and CD62L expression on OT-II CD4 ${ }^{+}$T cells at each time point during the coculture with OP9 (upper) or OP9-DL1 (lower) cells. CD62L ${ }^{+}$cells induced by coculturing with OP9 cells are indicated in a sky-blue square (upper). Naive T cells $\left(1 \times 10^{6}\right)$ were activated with OVA-DCs, then FACS-sorted CD44 ${ }^{\text {hi }}$ activated T cells $\left(1-1.5 \times 10^{6}\right)$ were cocultured with OP9 or OP9-DL1 cells. CD44 ${ }^{\text {hi }}$ CD62 $\mathrm{L}^{\text {hi }} \mathrm{iT}_{\mathrm{CM}}$ and $\mathrm{CD} 44^{\mathrm{lo}} \mathrm{CD} 62 \mathrm{~L}^{\text {hi }}$ naive-like $\mathrm{iT}_{\mathrm{SCM}}$ cells induced by OP9-DL1 cells are indicated in the blue and red squares, respectively (lower). Representative data of 4 independent experiments are shown. (c) The cell number of gated cell population at each time point in $\mathbf{b}(n=3)$. (d) Effects of a $\gamma$-secretase inhibitor DAPT on the induction of CD4 ${ }^{+} \mathrm{iT}_{\mathrm{SCM}}$ cells. Wild-type activated CD4 ${ }^{+}$T cells were cocultured with OP9 or OP9-DL1 cells with or without the presence of DAPT for four days ( $n=3$ per group). (e) Effects of a Notch ligand Fc protein (mDLL1-Fc) on the induction of CD4 ${ }^{+} \mathrm{iT}_{\mathrm{scm}}$ cells. Wild-type activated CD4 ${ }^{+} \mathrm{T}_{\text {cells }}$ were cultured with platebound mDLL1-Fc for four days ( $n=3$ per group). (f) Effects of overexpression of Notch ICDs on the induction of CD4 ${ }^{+} \mathrm{iT}_{\mathrm{SCM}}$ cells ( $n=3$ per group). Notch1 or Notch2 ICDs were retrovirally transduced into CD4 ${ }^{+}$T cells upon TCR stimulation. Notch1 or Notch2 ICD-transduced T cells were sorted as $\mathrm{CD} 4{ }^{+} \mathrm{CD} 44^{\text {hi }}$ Thy $1.1^{+}$cells. Sorted cells were consequently cocultured with OP9 cells for four days. ${ }^{\star \star} P<0.01$ (Student's $t$-test). Data are representative of at least two independent experiments. Error bars show s.e.m.

Fig. 3), and then cocultured the sorted single CD4 ${ }^{+} \mathrm{T}$ cells with OP9-DL1 or OP9 cells. As a result, whereas all the clones cocultured with OP9-DL1 cells produced CD44 ${ }^{\mathrm{lo}} \mathrm{CD} 62 \mathrm{~L}^{\text {hi }} \mathrm{iT}_{\mathrm{SCM}}$ cells, none of the clones with OP9 cells did (Supplementary Fig. 3). These results indicated that Notch signalling induced phenotypically naive-like $\mathrm{T}$ cells from activated $\mathrm{CD} 4^{+} \mathrm{T}$ cells.

Characterization of $\mathrm{CD}^{+} \mathbf{i T}_{\mathrm{SCM}}$ cells. The cell size of $\mathrm{iT}_{\mathrm{SCM}}$ cells were smaller than that of activated $\mathrm{CD} 4{ }^{+} \mathrm{T}$ cells and $\mathrm{iT}_{\mathrm{CM}}$ cells and close to that of naive $\mathrm{T}$ cells (Fig. 2a). Stem-like cells have been shown to express drug transporter including
ATP-binding cassette sub-family G member 2 (ABCG2), which rapidly efflux lipophilic fluorescent dyes ${ }^{19}$, thus exhibit so called 'side population (SP)' fraction in flow cytometry. $\mathrm{CD}_{4}^{+} \mathrm{iT}_{\mathrm{SCM}}$ cells showed more SP cells than $\mathrm{CD}^{+}{ }^{+} \mathrm{iT}_{\mathrm{CM}} \mathrm{T}$ cells did (Fig. 2b), and this fraction was decreased by the ABCG2 inhibitor Fumitremorgin $\mathrm{C}$ (FTC). These data suggest that $\mathrm{CD}^{+} \mathrm{iT}_{\mathrm{SCM}}$ cells may have a characteristic feature related to stem cells.

FACS analysis revealed that the coculturing with OP9-DL1 cells suppressed the expressions of exhausted and/or anergic $\mathrm{T}$ cell markers, PD-1 and CTLA-4, but strongly induced Bcl-2 expression (Fig. 2c,d). Notably, the expression level of CCR7 on $\mathrm{iT}_{\mathrm{SCM}}$ cells was comparable to that on the original naive 
a

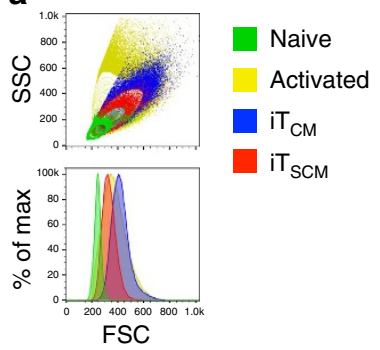

C

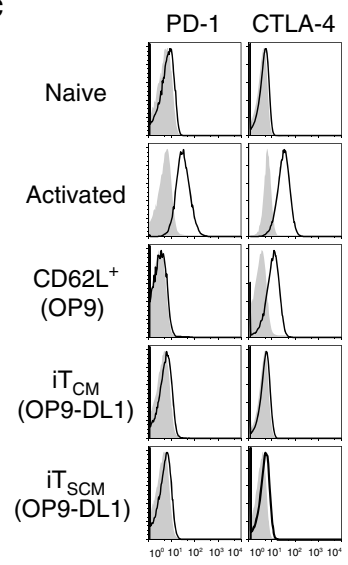

b
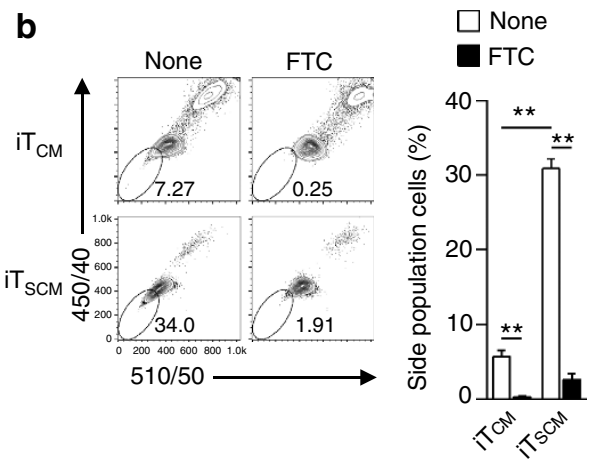

d

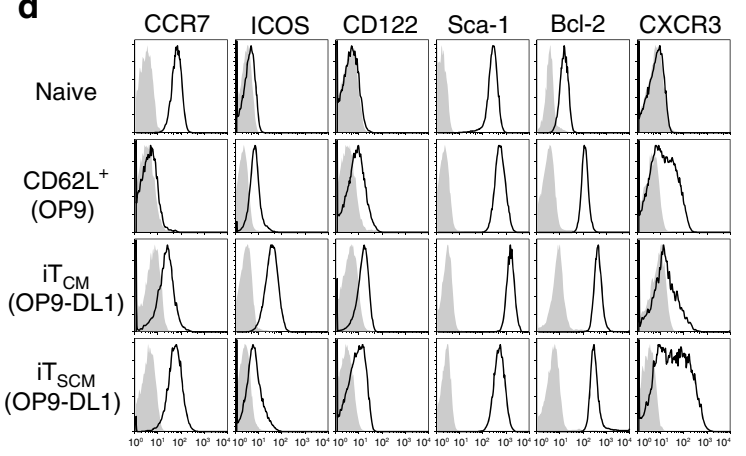

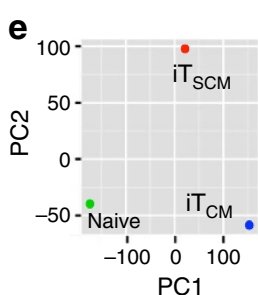

PC1

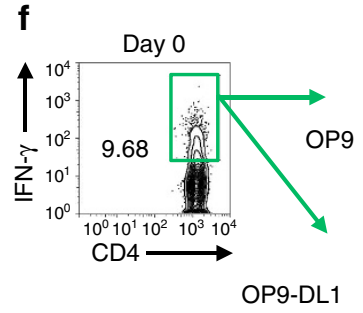

OP9-DL1

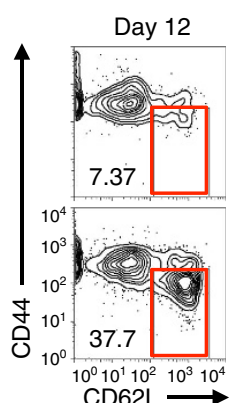

CD62 $\longrightarrow$
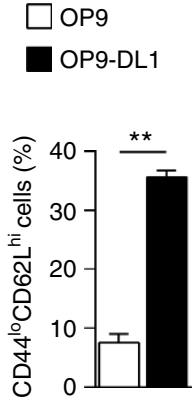

Figure 2 | Characterization of CD4 ${ }^{+} \mathbf{i T}_{\mathbf{S C M}}$ cells. (a) Flow cytometry analysis for cell sizes. Cell sizes are evaluated as relative values of forward scatter (FSC). Representative data of 3 independent experiments are shown. (b) SP assays were performed as described in the Methods section. Representative dot plots (left). The bar graphs show the percentages of SP cells $(n=3)$ (right). (c,d) Flow cytometry analysis for the expression of surface markers and intracellular $\mathrm{BCl}-2$ in naive $\mathrm{CD} 4{ }^{+} \mathrm{T}, \mathrm{CD}_{2} \mathrm{~L}^{+} \mathrm{CD} 4^{+} \mathrm{T}, \mathrm{CD} 4{ }^{+} \mathrm{iT}_{\mathrm{CM}}$ and $\mathrm{CD} 4{ }^{+} \mathrm{iT}_{\mathrm{SCM}}$ cells. (e) Principal component analysis of naive $\mathrm{CD} 4{ }^{+} \mathrm{T}$, $\mathrm{CD}^{+}{ }^{+} \mathrm{iT}_{\mathrm{CM}}$, and $\mathrm{CD} 4{ }^{+}$naive-like T cells ( $\mathrm{iT}_{\mathrm{SCM}}$ ). (f) Induction of CD4 ${ }^{+} \mathrm{iT}_{\mathrm{SCM}}$ cells from in vivo-primed Th1 cells by coculturing with OP9 or OP9-DL1 cells. CD4 ${ }^{+}$T cells isolated from immunized CD45.2+ OT-II Ifng Venus mice were transferred into CD45.1 ${ }^{+}$congenic mice, followed by immunization with OVA/CFA. Six days later, CD45.2 ${ }^{+} \mathrm{IFN}-\gamma+\mathrm{CD} 44^{\mathrm{hi}} \mathrm{CD} 4{ }^{+}$T cells (green square) were purified, and then cocultured with OP9-DL1 cells for 12 days. The $\mathrm{iT}_{\mathrm{SCM}}$-like gate is indicated by the red square ( $n=3$ per each groups). ${ }^{\star \star} P<0.01$ (Student's $t$-test). Data are representative of two independent experiments (a-d,f) and microarray data are acquired by single experiment (e). Error bars show s.e.m.

$\mathrm{CD} 4^{+} \mathrm{T}$ cells (Fig. 2d). Compared with the $\mathrm{CD} 44^{\mathrm{hi}} \mathrm{CD} 62 \mathrm{~L}$ hi $\mathrm{iT}_{\mathrm{CM}}$ cells, the CD44 ${ }^{\mathrm{lo}} \mathrm{CD} 62 \mathrm{~L}^{\mathrm{hi}}$ iT $_{\mathrm{SCM}}$ cells expressed lower levels of ICOS and a higher level of CXCR3, which are characteristic markers of $\mathrm{T}_{\mathrm{SCM}}$ and $\mathrm{T}_{\mathrm{MNP}}$ cells ${ }^{10,11}$, and these cells also showed

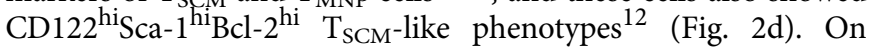
the other hand, the CD62L-positive $\mathrm{T}$ cells (designated as CD62L ${ }^{+} \mathrm{T}$ cells) induced by coculture with OP9 control feeder cells expressed higher levels of CTLA-4 and lower levels of CCR7 and Bcl-2 compared with $\mathrm{iT}_{\mathrm{CM}}$ and $\mathrm{iT}_{\mathrm{SCM}}$ cells (Fig. $2 \mathrm{c}, \mathrm{d}$ ). Furthermore, surface phenotypes of $\mathrm{CD} 44^{\mathrm{lo}}$ cells in $\mathrm{CD} 62 \mathrm{~L}^{+}$ $\mathrm{T}$ cells were identical to those of $\mathrm{CD} 44^{\mathrm{hi}} \mathrm{CD} 6 \mathrm{~L}^{+}$cells (Supplementary Fig. 4). Thus, CD62L $\mathrm{L}^{+} \mathrm{T}$ cells induced by coculture with $\mathrm{OP9}$ cells are phenotypically different from $\mathrm{iT}_{\mathrm{SCM}}$ and $\mathrm{iT}_{\mathrm{CM}}$ cells.
Principal component analysis and clustering analysis indicated that a gene expression pattern of the $\mathrm{CD} 44^{\mathrm{lo}} \mathrm{CD} 62 \mathrm{~L}^{\mathrm{hi}} \mathrm{iT}_{\mathrm{SCM}}$ cells differed from that of both the original naive $\mathrm{CD} 4^{+} \mathrm{T}$ cells and the $\mathrm{CD} 44^{\mathrm{hi}} \mathrm{CD} 62 \mathrm{~L}^{\mathrm{hi}} \mathrm{iT}_{\mathrm{CM}}$ cells (Fig. 2e and Supplementary Fig. 5a). Expression levels of various cytokines and transcription factors were very different among naive, $\mathrm{iT}_{\mathrm{CM}}$ and $\mathrm{iT}_{\mathrm{SCM}}$ cells (Supplementary Fig. 5b). Collectively, these results indicated that Notch signal-induced naive-like $\mathrm{CD} 4{ }^{+} \mathrm{T}$ cells $\left(\mathrm{CD} 4{ }^{+}{ }^{\mathrm{iT}} \mathrm{T}_{\mathrm{SCM}}\right.$ cells) were a unique subset with stem cell memory $\mathrm{T}$ cell characteristics.

Coculturing with OP9-DL1 cells induced $\mathrm{CD}^{+}{ }^{+} \mathrm{iT}_{\mathrm{SCM}}$ cells not only from Th1 cells but also from Th2 and Th17 cells (Supplementary Fig. 6a). $\mathrm{CD}^{+}{ }^{+} \mathrm{iT}_{\mathrm{SCM}}$ cells derived from Th1 

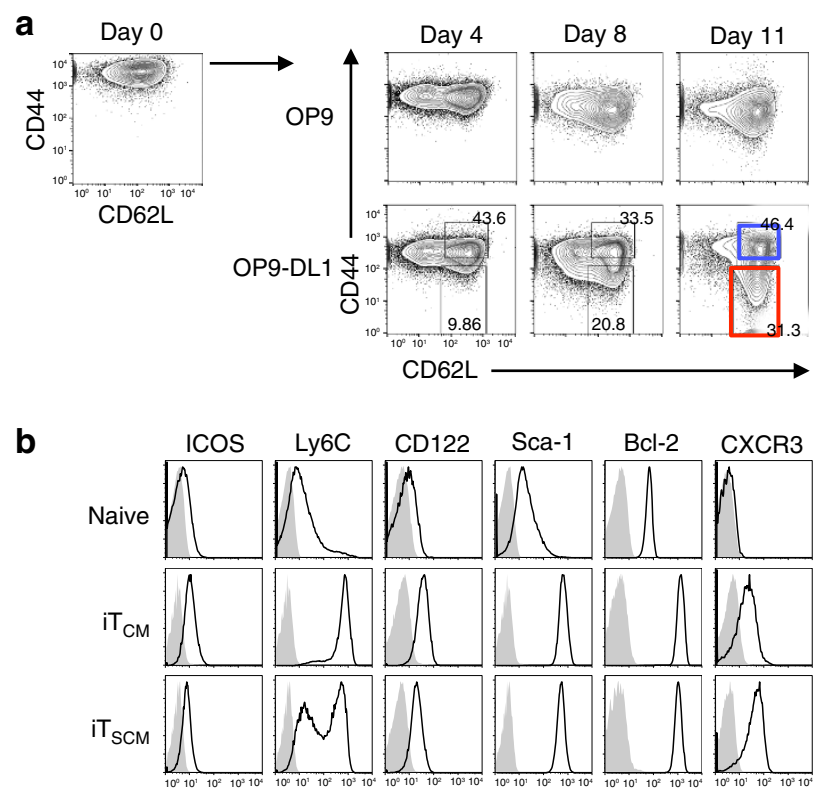

Figure 3 | Induction of $\mathbf{C D 8}^{+} \mathbf{i T}_{\mathbf{S C M}}$ cells via Notch signalling. (a) $\mathrm{CD} 44$ and CD62L expression on OT-I CD8 ${ }^{+}$T cells at each time point during the coculture with OP9 (upper) or OP9-DL1 (lower) cells. CD8 ${ }^{+} \mathrm{iT}_{\mathrm{CM}}$ and $\mathrm{iT}_{\mathrm{SCM}}$ cells are indicated by blue and red squares, respectively. (b) Flow cytometry analysis for the expression of surface markers and intracellular $\mathrm{BCl}-2$ in naive $\mathrm{CD} 8{ }^{+} \mathrm{T}, \mathrm{CD} 8{ }^{+} \mathrm{iT}_{\mathrm{CM}}$ and $\mathrm{CD} 8{ }^{+} \mathrm{iT}_{\mathrm{SCM}}$ cells. Representative data of three independent experiments are shown in (a) and (b).

cells produced a large number of IFN- $\gamma^{+}$cells, when restimulated with OVA-DCs under any Th-polarizing conditions in vitro (Supplementary Fig. 6b). Similarly, only IFN- $\gamma^{+}$effector cells were detected in vivo when Thl cell-derived $\mathrm{iT}_{\mathrm{SCM}}$ or $\mathrm{iT}_{\mathrm{CM}}$ cells were administered into OT-II mice then immunized with OVA/incomplete Freund's adjuvant (IFA)(Supplementary Fig. 6c), suggesting that the cytokine-producing profiles are imprinted in $\mathrm{CD}^{+} \mathrm{iT}_{\mathrm{SCM}}$ cells from the original $\mathrm{Th}$ subsets. We also found that the OP9-DL1 cell coculture system generated $\mathrm{CD}^{+}{ }^{+} \mathrm{iT}_{\mathrm{SCM}}$ cells from in vivo-induced Th1 cells that were derived from IFN- $\gamma$ reporter OT-II mice (Ifng ${ }^{\mathrm{Venus}}$ ) immunized with OVA/complete Freund's adjuvant (CFA) (Fig. 2f).

Induction of $\mathrm{CD8}^{+} \mathrm{iT}_{\mathrm{SCM}}$ cells by Notch signalling. Next, we attempted to induce $\mathrm{CD} 8{ }^{+}{ }^{-} \mathrm{T}_{\mathrm{SCM}}$ cells using the OP9-DL1 cell coculture system. First, we activated OVA-specific $\mathrm{CD} 44^{\mathrm{lo}} \mathrm{CD} 62 \mathrm{~L}^{\mathrm{hi}}$ naive $\mathrm{CD} 8^{+} \mathrm{T}$ cells from OT-I mice by coculturing with OVA-DCs. Four days later, CD44 ${ }^{\text {hi }}$ activated $\mathrm{T}$ cells, which expressed Notch1 and Notch2, but not Notch3, and showed the memory precursor cell phenotypes (Supplementary Fig. 2a,c), were cocultured with OP9-DL1 or OP9 cells in the presence of IL-7 and anti-IFN- $\gamma$ neutralizing $\mathrm{Ab}$ for 11 days. As a result, $\mathrm{CD} 44^{\mathrm{lo}} \mathrm{CD} 62 \mathrm{~L}^{\text {hi }}$ naive-like $\mathrm{T}$ cells were induced by coculturing with OP9-DL1, but not OP9, cells (Fig. 3a). Coculturing with OP9-DL1 cells upregulated $\mathrm{CD} 122$, Sca-1 and $\mathrm{Bcl}-2$ expression on both $\mathrm{CD} 44^{\mathrm{lo}} \mathrm{CD} 62 \mathrm{~L}^{\mathrm{hi}}$ naive-like iT $\mathrm{T}_{\mathrm{SCM}}$ cells and $\mathrm{CD} 444^{\mathrm{hi}} \mathrm{CD} 62 \mathrm{~L}^{\text {hi }} \mathrm{iT}_{\mathrm{CM}}$ cells (Fig. $3 \mathrm{~b}$ ). However, $\mathrm{CD}^{+}{ }^{+} \mathrm{iT}_{\mathrm{SCM}}$ cells expressed lower levels of ICOS and Ly6C, and a higher level of CXCR3, compared with the $\mathrm{iT}_{\mathrm{CM}}$ cells (Fig. $3 \mathrm{~b}$ ). These results indicated that coculture with OP9-DL1 cells induces iT $\mathrm{T}_{\mathrm{SCM}}$ cells from activated $\mathrm{CD}^{+}{ }^{+} \mathrm{T}$ cells as well.
Stem cell memory properties of antigen-specific $\mathrm{iT}_{\mathrm{SCM}}$ cells. Then, we examined whether $\mathrm{iT}_{\mathrm{SCM}}$ cells actually possess functional stem cell memory-like phenotypes. First, cell division in response to TCR stimulation was compared among naive $\mathrm{CD} 4{ }^{+} \mathrm{T}$ cells, in vivo $\mathrm{CD} 4{ }^{+} \mathrm{T}_{\mathrm{EM}}$ and $\mathrm{T}_{\mathrm{CM}}$ cells, in vitrogenerated Th1 cells, and Th1-derived $\mathrm{iT}_{\mathrm{CM}}$ and $\mathrm{iT}_{\mathrm{SCM}}$ cells. All these $\mathrm{T}$ cells were prepared from Rag2 ${ }^{-1}$ - OT-II mice, therefore, uniformly carried OVA-specific TCR. We found that $\mathrm{CD} 4^{+}$ $\mathrm{iT}_{\mathrm{SCM}}$ cells proliferated more rapidly than any of the other subsets after stimulation with OVA-DCs (Fig. 4a). OVA-specific CD8 ${ }^{+}$ $\mathrm{iT}_{\mathrm{SCM}}$ cells also highly proliferated in vitro in response to OVA restimulation compared with naive $\mathrm{CD} 8^{+} \mathrm{T}$ and $\mathrm{iT}_{\mathrm{CM}}$ cells (Supplementary Fig. 7a). The in vitro proliferation activity of CD62 $\mathrm{L}^{+} \mathrm{CD} 44^{\text {hi }}$ and $\mathrm{CD} 62 \mathrm{~L}^{+} \mathrm{CD} 44^{\text {lo }} \mathrm{T}$ cells induced by $\mathrm{OP9}$ cell coculture was inferior to that of $\mathrm{iT}_{\mathrm{SCM}}$ cells (Supplementary Fig. $7 \mathrm{~b}$ ). We also found that antigen-activated $\mathrm{iT}_{\mathrm{SCM}}$ cells retained rapid proliferation potential in the secondary coculture with OP9-DL1 cells (Supplementary Fig. 7c).

To investigate their short term proliferation capacity in vivo, we transferred each of the CFSE-labelled congenically marked CD $45.1^{+} \mathrm{CD} 4{ }^{+}$OT-II T cell subsets into CD45.2 ${ }^{+}$wild-type mice, then immunized the mice with OVA. Three and six days later, the numbers of proliferated $\mathrm{T}$ cells derived from $\mathrm{CD} 4^{+} \mathrm{iT}_{\mathrm{SCM}}$ cells in the secondary lymphoid organs were significantly greater than those from any of the other subsets (Fig. $4 \mathrm{~b}$ for three days and Supplementary Fig. 7d,e for six days).

To assess the proliferation capacity under homoeostatic conditions in vivo, CFSE-labelled naive $\mathrm{T}$ cells, $\mathrm{T}_{\mathrm{CM}}$ cells from immunized mice, $\mathrm{iT}_{\mathrm{CM}}$ or $\mathrm{iT}_{\mathrm{SCM}}$ cells from Rag2 ${ }^{-1-} \mathrm{OT}-\mathrm{II}$ mice were transferred into sublethally irradiated congenic mice. After 20 days, a larger number of $\mathrm{iT}_{\mathrm{SCM}}$ cells were recovered, and about $70 \%$ of the $\mathrm{T}$ cells derived from the $\mathrm{CD}^{+}{ }^{+} \mathrm{iT}_{\mathrm{SCM}}$ cells retained CD44 ${ }^{\text {lo }} \mathrm{CD} 62 \mathrm{~L}^{\text {hi }} \mathrm{T}_{\mathrm{SCM}}$ phenotypes and divided significantly better than naive $\mathrm{T}$ cells, $\mathrm{T}_{\mathrm{CM}}$ and $\mathrm{iT}_{\mathrm{CM}}$ cells did (Fig. 4c). Even 150 days later, significantly greater numbers of $\mathrm{T}$ cells derived from the $\mathrm{CD} 4{ }^{+} \mathrm{iT}_{\mathrm{SCM}}$ cells were observed in the secondary lymphoid organs compared with those from naive $\mathrm{CD} 4{ }^{+} \mathrm{T}$ and the $\mathrm{iT}_{\mathrm{CM}}$ cells, and about $70 \%$ of the $\mathrm{T}$ cells from the $\mathrm{CD}^{+}{ }^{+} \mathrm{iT}_{\mathrm{SCM}}$ cells retained $\mathrm{CD} 44^{\mathrm{lo}} \mathrm{CD} 62 \mathrm{~L}^{\mathrm{hi}}$ naive phenotypes (Fig. 5a for cell numbers 150 days after transplantation and Supplementary Fig. 8 for time course experiments). These results indicated that antigen-specific $\mathrm{iT}_{\mathrm{SCM}}$ cells possessed the great capacity not only to proliferate in response to antigen restimulation but also to survive for an extended time under homoeostatic conditions.

Next, to investigate whether $\mathrm{CD}^{+} \mathrm{iT}_{\mathrm{SCM}}$ cells possess a self-renewal capacity in vivo, we performed serial transfer experiments; we purified CFSE ${ }^{\mathrm{lo}} \mathrm{CD} 44^{\mathrm{lo}} \mathrm{CD} 62 \mathrm{~L}^{\text {hi }} \mathrm{CD} 4{ }^{+} \mathrm{T}$ cells derived from naive $\mathrm{CD} 4{ }^{+} \mathrm{T}$ or $\mathrm{CD} 4{ }^{+}{ }^{-} \mathrm{iT}_{\mathrm{SCM}}$ cells from the first transferred mice, transferred them into the second mice and performed the same procedures for the third mice. In the case of $\mathrm{CD} 4{ }^{+} \mathrm{iT}_{\mathrm{CM}}$ cells, we purified and transferred $\mathrm{CFSE}^{\mathrm{lo}} \mathrm{CD} 44-$ ${ }^{\mathrm{C}} \mathrm{CD} 62 \mathrm{~L}^{\text {hi }} \mathrm{CD} 4{ }^{+} \mathrm{T}$ cells. $\mathrm{CD} 4{ }^{+} \mathrm{T}$ cells derived from the $\mathrm{CD} 4{ }^{+}$ $\mathrm{iT}_{\mathrm{SCM}}$ cells were successfully detected in the second lymphoid organs of the third transferred mice, while naive $\mathrm{CD} 4^{+} \mathrm{T}$ and $\mathrm{CD} 4{ }^{+} \mathrm{iT}_{\mathrm{CM}}$ cells failed to be detected in the second and third transferred mice, respectively (Fig. 5b), indicating that $\mathrm{CD} 4{ }^{+} \mathrm{iT}_{\mathrm{SCM}}$ cells possess high self-renewal capacity in vivo. Collectively, these results suggested that $\mathrm{CD} 4{ }^{+} \mathrm{iT}_{\mathrm{SCM}}$ cells had stem cell-like potential.

Reduced expression of p53 in $\mathrm{iT}_{\mathrm{SCM}}$ cells. Then, we investigated the mechanism of a high proliferation potential of $\mathrm{iT}_{\mathrm{SCM}}$ cells. Rapid proliferation and the extended survival of $\mathrm{CD} 4{ }^{+} \mathrm{iT}_{\mathrm{SCM}}$ cells was not due to high expression of IL-2 or higher sensitivity 

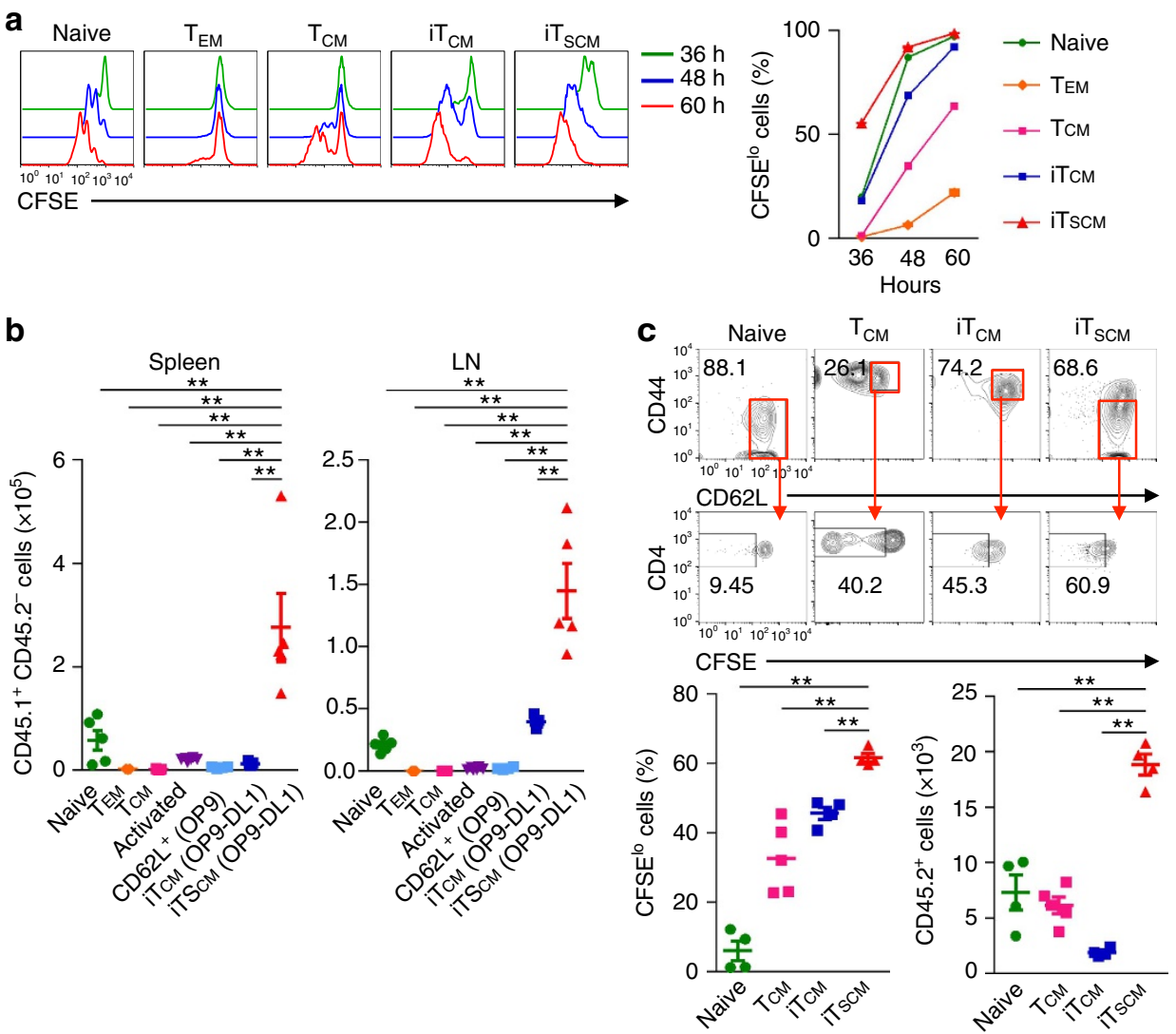

Figure 4 | Murine CD4 ${ }^{+} \mathbf{i T}_{\mathbf{S C M}}$ cells possess high proliferation ability. (a) Cell division of CD4 ${ }^{+}$T cells after stimulation with OVA-DCs in vitro assessed by CFSE-dilution assay. Naive CD4 ${ }^{+}$T cells, $T_{E M}$, and $T_{C M}$ cells were isolated from immunized Rag $2^{-/-}$OT-II mice, and $\mathrm{iT}_{\mathrm{CM}}$, and $\mathrm{iT}_{\mathrm{SCM}}$ cells were generated from in vitro activated Rag2 ${ }^{-/-}$OT-II CD4 ${ }^{+}$T cells. These cells were CFSE labelled, then stimulated with OVA-DCs for indicated periods. CFSE profiles and the fraction of CFSE ${ }^{l o}$ proliferated cells are shown $(n=3)$. (b) In vivo expansion of $\mathrm{iT}_{\mathrm{SCM}}$ and other type of CD4 ${ }^{+} \mathrm{T}_{\text {cells }}$ after antigen restimulation. $\mathrm{CD} 45.1^{+} \mathrm{CD} 4+$ OT-II naive T cells, $\mathrm{T}_{\mathrm{EM}}, \mathrm{T}_{\mathrm{CM}}$ cells, CD62L ${ }^{+}$cells, $\mathrm{iT}_{\mathrm{CM}}$ and $\mathrm{iT}_{\mathrm{SCM}}\left(2 \times 10^{5}\right)$ were transferred into $\mathrm{CD} 45.2^{+}$mice, followed by OVA/IFA immunization. Three days later, cell numbers in the spleen and LNs were counted ( $n=5$ per group). (c) In vivo expansion of CD4 ${ }^{+} \mathrm{iT}_{\mathrm{sCM}}$ cells under homoeostatic conditions. CFSE-labelled $5 \times 10^{5}$ cells were injected into the sublethally irradiated recipient mice, then 20 days later, $T$ cells were isolated and analysed CD44/CD62L expression and CFSE profiles. The percentage of CFSE ${ }^{\text {o } C D 44}{ }^{10} \mathrm{CD} 62 \mathrm{~L}^{\text {hi }}$ fraction for iT $\mathrm{SCM}$ cells or naive T cells, and that of $C F S E^{l o} C D 44{ }^{h i} C D 62 L^{\text {hi }}$ fraction for $T_{C M}$ and $i T_{C M}$ cells as well as the total cell numbers recovered from the spleen and $L N s$ are shown. ${ }^{\star \star} P<0.01$ (one-way ANOVA (a-c)). Data are representative of at least two independent experiments. Error bars show s.e.m.

to IL-2: OVA-specific $\mathrm{CD}^{+}{ }^{+} \mathrm{iT}_{\mathrm{SCM}}$ cells produced less but sufficient amounts of IL-2 after stimulation with OVA-DCs (Supplementary Fig. 9a). In addition, there were no differences in the phosphorylation levels of Stat5 and Akt, which are downstream of the IL-2 receptor signalling pathway, between $\mathrm{CD}^{+}{ }^{+} \mathrm{iT}_{\mathrm{SCM}}$ and $\mathrm{iT}_{\mathrm{CM}}$ cells (Supplementary Fig. $9 \mathrm{~b}$ ). We noticed that $\mathrm{CD}^{+}{ }^{+} \mathrm{iT}_{\mathrm{SCM}}$ cells composed a higher proportion of G2/M and $S$ phases even on Day 1 after stimulation compared with $\mathrm{CD} 4{ }^{+} \mathrm{iT}_{\mathrm{CM}}$ cells and naive $\mathrm{CD} 4{ }^{+} \mathrm{T}$ cells, which required 2-3 days to enter G2/M and S phases (Supplementary Fig. 10a). We also found that apoptosis of $\mathrm{CD}^{+} \mathrm{iT}_{\mathrm{SCM}}$ cells after TCR restimulation was significantly lower than $\mathrm{CD}^{+}{ }^{+} \mathrm{iT}_{\mathrm{CM}}$ cells did (Supplementary Fig. 10b).

The tumour suppressor gene p53 is known to be a regulatory factor in cell cycle arrest and apoptosis ${ }^{20}$. It has been proposed the multilevel crosstalk between the Notch pathway and the p53 pathways ${ }^{21}$. The Notch signal has been shown to suppress p53 expression in $\mathrm{T}$ cell lymphoma cells ${ }^{22}$. p53 expression levels in $\mathrm{CD}^{+}{ }^{+} \mathrm{iT}_{\mathrm{SCM}}$ cells were significantly lower than that of $\mathrm{CD}^{+}{ }^{+}$naive and $\mathrm{iT}_{\mathrm{CM}}$ cells in vitro and in vivo (Supplementary Fig. 10c,d). Consistently, $\mathrm{CD}^{+} \mathrm{iT}_{\mathrm{SCM}}$ cells expressed significantly lower levels of p53 target genes: a p53-specific E3 ubiquitin ligase $M d m 2$, cell growth arrest genes Gadd45a and
Ptprv, and apoptosis regulation genes Bax, Bbc3 and Fas (Supplementary Fig. 10e). Degradation of p53 by $\mathrm{Mdm} 2$ has been reported to be critical for $\mathrm{CD} 4{ }^{+} \mathrm{T}$ cell proliferation on TCR stimulation $^{23}$. Mdm2 inhibitor Nutlin3a decreased the G2/M phase proportion and increased AnnexinV ${ }^{+} \mathrm{PI}^{+}$apoptotic cells (Supplementary Fig. 10f), suggesting that p53 reduction is involved in higher proliferation and lower apoptotic potentials of $\mathrm{iT}_{\mathrm{SCM}}$ cells. $\mathrm{CD} 8^{+} \mathrm{iT}_{\mathrm{SCM}}$ cells also composed a higher proportion of $\mathrm{G} 2 / \mathrm{M}$ and $\mathrm{S}$ phases and fewer AnnexinV ${ }^{+} \mathrm{PI}^{+}$ apoptotic cells than $\mathrm{CD}^{+} \mathrm{iT}_{\mathrm{CM}}$ cells did (Supplementary Fig. 11a,b), which is related to a lower expression of p53 and its target genes than in $\mathrm{CD}^{+} \mathrm{iT}_{\mathrm{CM}}$ cells (Supplementary Fig. $11 \mathrm{c}, \mathrm{d})$. These results suggested that lower expression levels of p53 and its targets molecules in $\mathrm{iT}_{\mathrm{SCM}}$ cells could be a mechanism for $\mathrm{iT}_{\mathrm{SCM}}$ cells to be resistant to cell cycle arrest and apoptosis after TCR stimulation.

Potent antitumour activity of $\mathbf{i T}_{\mathrm{SCM}}$ cells. $\mathrm{iT}_{\mathrm{SCM}}$ cells showed strong proliferation upon TCR restimulation with resistance to cell cycle arrest and apoptosis, which suggested that $\mathrm{iT}_{\mathrm{SCM}}$ cells were more likely to be applicable to cancer immunotherapy 8,24 . Thus, we investigated the antitumour effects of $\mathrm{iT}_{\mathrm{SCM}}$ cells using 


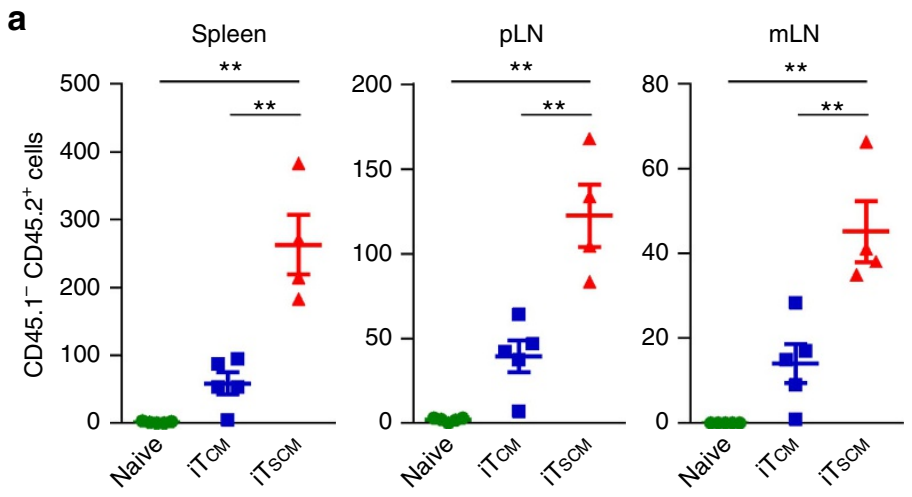

b

CFSE-labelled

Naive, $\mathrm{iT}_{\mathrm{CM}}$, $\mathrm{iT}_{\mathrm{SCM}}$ i.v.
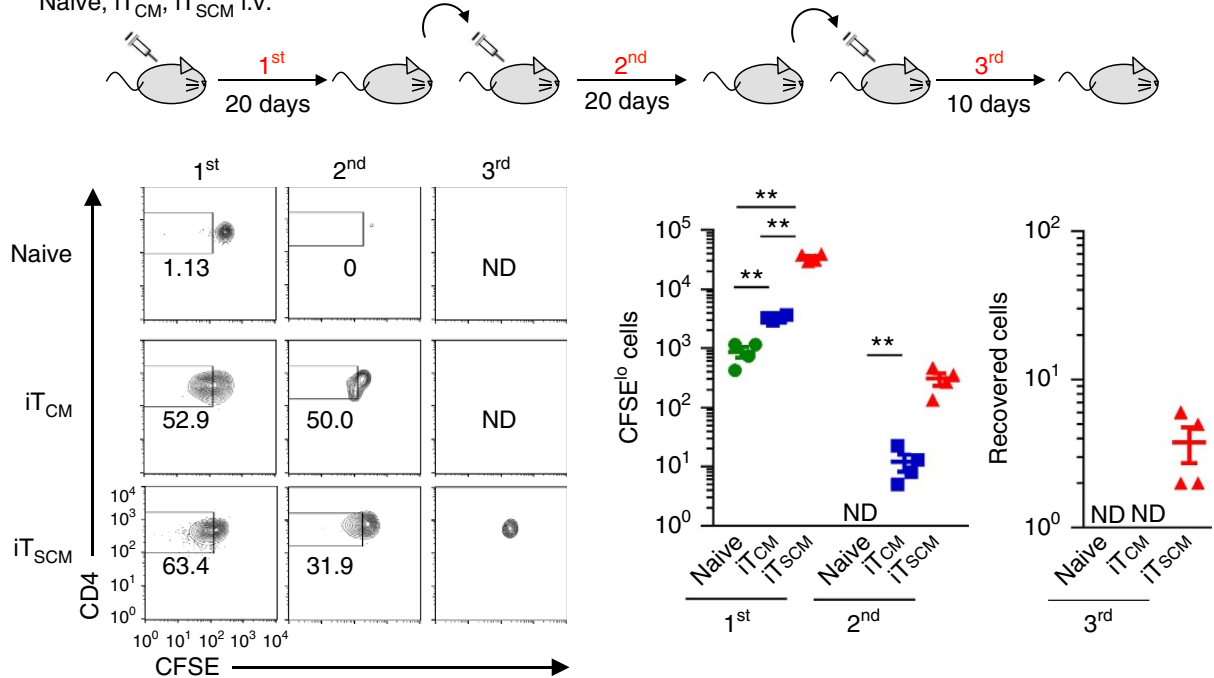

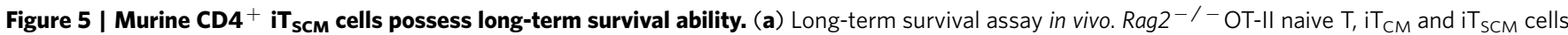
$\left(5 \times 10^{4}\right)$ were adoptively transferred into sublethally irradiated CD45.1 $1^{+}$congenic mice. After 150 days, numbers of the CD45.2 ${ }^{+} \mathrm{T}$ cells were determined

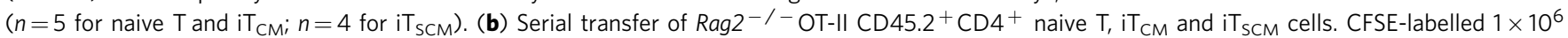
T cells were injected into the CD45.1 ${ }^{+}$recipient mice (first transfer). On day $20, \mathrm{CFSE}{ }^{\mathrm{lo}} \mathrm{CD} 44^{\mathrm{lo}} \mathrm{CD} 62 \mathrm{~L}^{\text {hi }}$ fraction for $\mathrm{iT}$ SCM cells or naive T cells, or

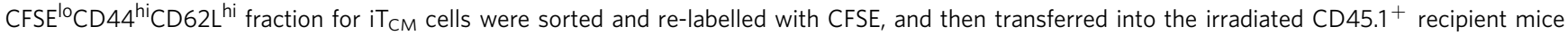
(second transfer). Twenty days later, the same procedure was performed as third transfer, and mice were analysed on day 10 after third transfer. CFSE profiles in $\mathrm{CD}_{4} 4^{\mathrm{lo}} \mathrm{CD} 62 \mathrm{~L}^{\text {hi }}$ fraction for $\mathrm{iT}_{\mathrm{SCM}}$ cells or naive T cells, or $\mathrm{CD} 44^{\text {hi }} \mathrm{CD} 62 \mathrm{~L}$ hi fraction for $\mathrm{iT}_{\mathrm{CM}}$ cells are shown in left panels. The actual numbers of the recovered CFSE ${ }^{10}$ cells after first and second transfer and the number of whole cells recovered after third transfer are shown in right graphs ( $n=5$ per group). ND, not detectable. ${ }^{\star \star} P<0.01$ (one-way ANOVA $(\mathbf{a}, \mathbf{b})$ ). Data are representative of at least two independent experiments.

Error bars show s.e.m.

T cell lymphoma cell line E.G7-OVA-bearing mice. First we transferred $\mathrm{CD} 8{ }^{+}{ }^{\mathrm{iT}} \mathrm{T}_{\mathrm{CM}}$ and $\mathrm{iT}_{\mathrm{SCM}}$ cells derived from OT-I mice into E.G7-OVA-bearing mice. After 36 hours, $\mathrm{CD} 8{ }^{+}{ }^{-} \mathrm{TT}_{\mathrm{SCM}}$ cells were detected in the sentinel lymph nodes, whereas much fewer $\mathrm{CD}^{+}{ }^{+} \mathrm{iT}_{\mathrm{CM}}$ cells were present (Fig. 6a). OVA-specific $\mathrm{CD} 8{ }^{+}$ $\mathrm{iT}_{\mathrm{SCM}}$ cells also proliferated faster in E.G7-OVA-bearing mice in response to OVA restimulation than OVA-specific $\mathrm{iT}_{\mathrm{CM}}$ cells did (Supplementary Fig. 12a). It has been reported that naive T cells are appropriate for cancer immunotherapy because of their stronger replicative potential compared to that of any other memory subset ${ }^{8}$. On the other hand, activated $\mathrm{T}$ cells that acquire effector functions in vitro presumably lose the antitumour efficacy in $v i v{ }^{4}$. Thus, we compared the antitumour effects against E.G7-OVA among naive CD8 ${ }^{+} \mathrm{T}$, OVA-activated $\mathrm{CD} 8{ }^{+}{ }^{+}$and $\mathrm{CD}^{+}{ }^{+} \mathrm{iT}_{\mathrm{SCM}}$ cells that were all derived from OT-I mice. As shown in Fig. 6b, OVA-specific $\mathrm{CD} 8^{+} \mathrm{iT}_{\mathrm{SCM}}$ cells showed significantly stronger suppressive effects on E.G7-OVA cell growth than OVA-specific naive $\mathrm{CD} 8^{+} \mathrm{T}$ and activated $\mathrm{CD} 8{ }^{+}$ $\mathrm{T}$ cells did. Consequently, OVA-specific $\mathrm{CD}^{+} \mathrm{iT}_{\mathrm{SCM}}$ cells improved the survival rates of the mice (Fig. 6b). Similarly, OVA-specific $\mathrm{CD}^{+}{ }^{+} \mathrm{iT}_{\mathrm{SCM}}$ cells also survived in the sentinel lymph nodes and suppressed E.G7-OVA cell growth more efficiently than $\mathrm{CD} 4{ }^{+} \mathrm{T}_{\mathrm{EM}}$ and $\mathrm{T}_{\mathrm{CM}}$ cells, $\mathrm{iT}_{\mathrm{CM}}$ cells, and $\mathrm{CD} 2 \mathrm{~L}^{+}$cells, although $\mathrm{CD} 4^{+} \mathrm{iT}_{\mathrm{SCM}}$ cells showed weaker tumour suppressing effects than $\mathrm{CD} 8{ }^{+} \mathrm{iT}_{\mathrm{SCM}}$ cells did (Supplementary Fig. 12b,c).

To investigate whether antigen-specific $\mathrm{CD} 4{ }^{+} \mathrm{iT}_{\mathrm{CM}}$ or $\mathrm{iT}_{\mathrm{SCM}}$ cells enhance the antitumour effects of the $\mathrm{CD}^{+}{ }^{+} \mathrm{iT}_{\mathrm{SCM}}$ cells, we transferred various combinations of OVA-specific $\mathrm{CD}^{+}$and $\mathrm{CD}^{+}{ }^{+} \mathrm{iT}_{\mathrm{CM}}$ or $\mathrm{iT}_{\mathrm{SCM}}$ cells into E.G7-OVA-bearing mice. The $\mathrm{CD}^{+}{ }^{+} \mathrm{iT}_{\mathrm{SCM}}$ cells exerted not only stronger suppressive effects against the E.G7-OVA cell growth but also better survival rates of the mice in combination with the $\mathrm{CD}_{4}^{+}{ } \mathrm{iT}_{\mathrm{SCM}}$ cells than alone or in combination with the $\mathrm{CD}^{+}{ }^{+} \mathrm{iT}_{\mathrm{CM}}$ cells (Fig. $6 \mathrm{c}, \mathrm{d}$ ). 
a
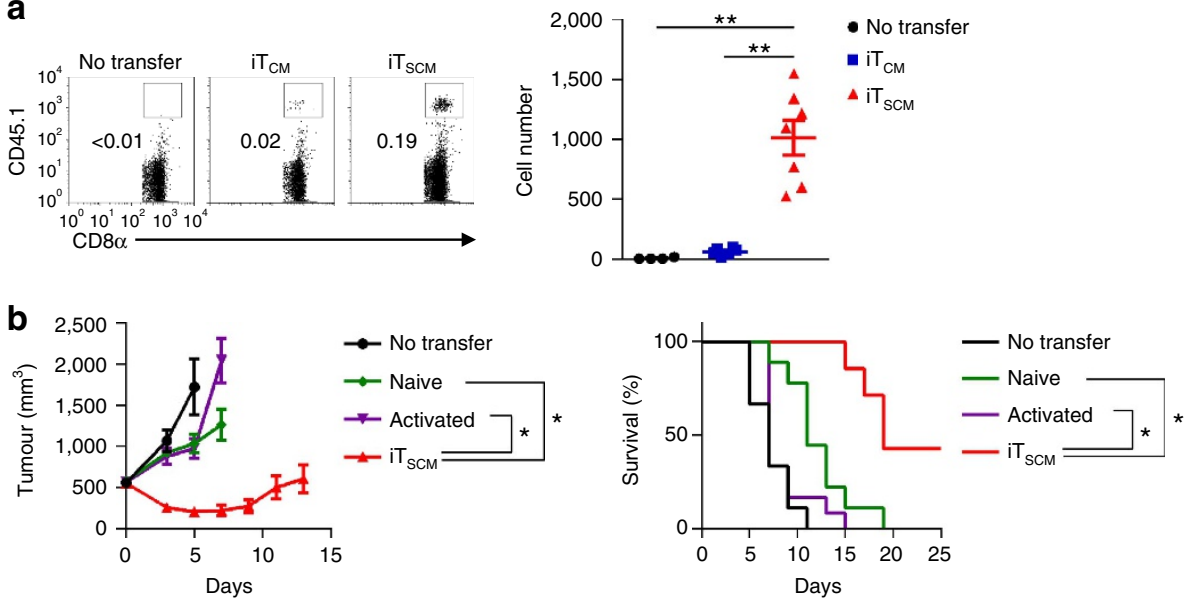

C
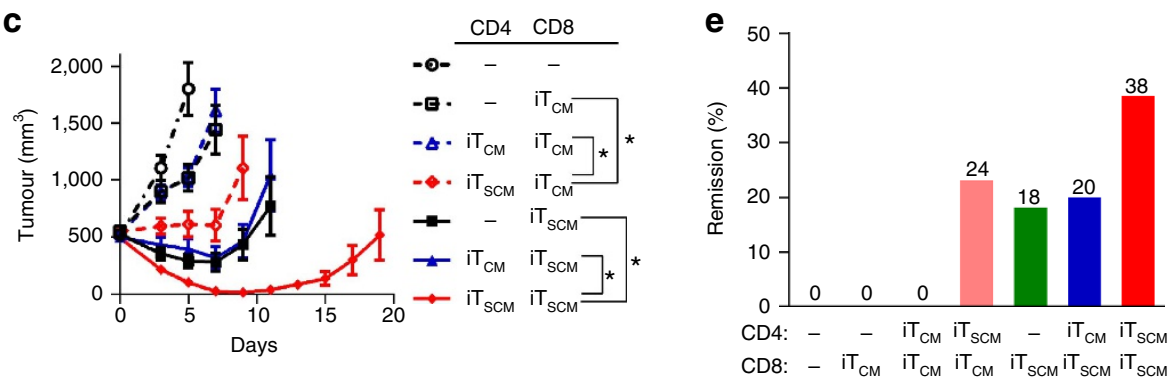

d

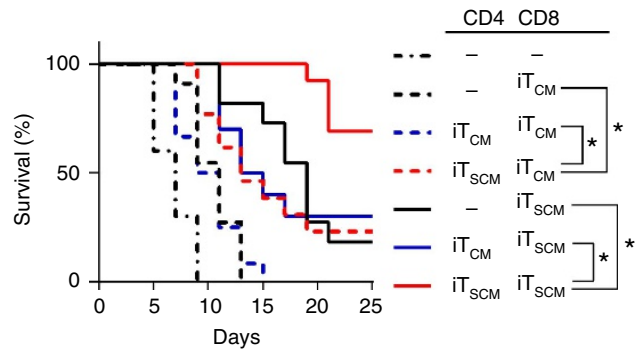

Figure 6 | Antitumour potential of murine $\mathbf{i T}_{\mathbf{s c m}}$ cells. (a) Flow cytometry analysis of OVA-specific CD8 ${ }^{+} \mathrm{T}_{\text {cells infiltrating into sentinel LNs. CD45.2 }}^{+}$ wild-type mice were inoculated with E.G7-OVA eight days before the transfer of $1.5 \times 10^{5} \mathrm{CD} 45.1^{+} \mathrm{OT}-\mathrm{I}$ CD8 ${ }^{+} \mathrm{iT}_{\mathrm{CM}}$ or $\mathrm{iT}_{\mathrm{SCM}}$ cells. T cells in the sentinel LNs were analysed by flow cytometry $36 \mathrm{~h}$ after the T cell transfer. Squares in the dot plots indicate CD45. $1^{+}$T cells (left). ( $n=4$ for no transfer; $n=6$ for $\mathrm{iT}_{\mathrm{CM}}$ cells; $n=7$ for $\mathrm{iT}_{\mathrm{SCM}}$ cells). (b) Tumour volumes (left) and survival rates (right) of E.G7-OVA-bearing mice. $3 \times 10^{5}$ naive CD8 ${ }^{+} \mathrm{T}, \mathrm{CD} 44^{\mathrm{hi}}$ activated $\mathrm{CD}^{+}{ }^{+}$, or $\mathrm{CD} 8{ }^{+} \mathrm{iT}_{\mathrm{SCM}}$ cells derived from OT-I mice were adoptively transferred into the E.G7-OVA-bearing mice $(n=9$ for no transfer and naive; $n=12$ for activated; $n=7$ for iT SCM). (c-e) The effect of combination of OT-I CD8 ${ }^{+} \mathrm{iT}_{\mathrm{CM}}$ or $\mathrm{iT} \mathrm{SCM}_{\mathrm{SC}}$, and OT-II CD4 ${ }^{+} \mathrm{iT}_{\mathrm{CM}}$ or $\mathrm{iT} \mathrm{TCM}_{\mathrm{SC}}$ cells on antitumour immunity. T cells $\left(3 \times 10^{5}\right.$ cells for each group) were adoptively transferred into E.G7-OVA-bearing mice. (c) Tumour volumes of E.G7-OVA-bearing mice. (d) Survival rates of E.G7-OVA-bearing mice. (e) Remission rates at 90 days after the adoptive T cell transfer. Data were collected from three independent experiments ( $n=10$ for no transfer; $n=11$ for CD8 ${ }^{+} \mathrm{iT}_{\mathrm{CM}} ; n=12$ for CD4 ${ }^{+} \mathrm{iT}_{\mathrm{CM}}$ and CD8 ${ }^{+} \mathrm{iT}_{\mathrm{CM}} ; n=13$ for CD4 ${ }^{+} \mathrm{iT}_{\mathrm{SCM}}$ and $\mathrm{CD} 8{ }^{+} \mathrm{iT}_{\mathrm{CM}} ; n=11$ for $\mathrm{CD} 8+\mathrm{iT}_{\mathrm{SCM}}$; $n=10$ for $\mathrm{CD}^{+}{ }^{+} \mathrm{iT}_{\mathrm{CM}}$ and $\mathrm{CD} 8{ }^{+} \mathrm{iT}_{\mathrm{SCM}} ; n=13$ for $\mathrm{CD} 4{ }^{+} \mathrm{iT}_{\mathrm{SCM}}$ and $\left.\mathrm{CD} 8+{ }^{+} \mathrm{iT}_{\mathrm{SCM}}\right)(\mathbf{c}, \mathbf{d}, \mathbf{e}) .{ }^{\star} P<0.05,{ }^{\star} * P<0.01$ (one-way ANOVA (a), Student's $t$-test (b left, $\mathbf{c}$ left), and the Kaplan-Meier method (b right, d)). Data are representative of at least two independent experiments. Error bars show s.e.m.

Consistent with the results of Fig. 6a, OVA-specific $\mathrm{CD}^{+}{ }^{+} \mathrm{iT}_{\mathrm{CM}}$ cells alone had some tumour-suppressive effects, however, combination with OVA-specific $\mathrm{CD}^{+} \mathrm{iT}_{\mathrm{SCM}}$ significantly improved the antitumour effects (Fig. $6 c, d$ ), and their combination induced remission in $24 \%$ of the mice (Fig. 6e). More importantly, the remission rate by OVA-specific $\mathrm{CD} 8{ }^{+} \mathrm{iT}_{\mathrm{SCM}}$ cells alone $(18 \%)$ was substantially improved to $38 \%$ by the combination with the $\mathrm{CD}^{+}{ }^{+} \mathrm{iT}_{\mathrm{SCM}}$ cells (Fig. 6e). These results suggested that antigenspecific $\mathrm{CD}^{+}{ }^{+} \mathrm{iT}_{\mathrm{SCM}}$ cells enhanced antitumour immune responses provided by antigen-specific $\mathrm{CD} 8{ }^{+} \mathrm{iT}_{\mathrm{SCM}}$ cells. Taken together, tumour antigen-specific $\mathrm{CD} 8^{+} \mathrm{iT}_{\mathrm{SCM}}$ cells are more likely to have potent antitumour effects, and the combination with the $\mathrm{CD}^{+}{ }^{+} \mathrm{iT}_{\mathrm{SCM}}$ cells and the $\mathrm{CD} 8{ }^{+}{ } \mathrm{iT}_{\mathrm{SCM}}$ cells are thought to provide the strongest antitumour effects.
Comparison between Wnt and Notch-induced $\mathbf{T}_{\mathrm{SCM}^{-}}$-like cells. We next compared the antitumour effects of Wnt signallinginduced $\mathrm{T}_{\mathrm{SCM}}$ cells and Notch signalling-induced $\mathrm{iT}_{\mathrm{SCM}}$ cells in mouse models. As shown previously ${ }^{12}$, TCR stimulation in the presence of TWS119, a Wnt activator, generated OVA-specific CD $44^{\text {lo }}{ }^{2}$ 62 $2 \mathrm{~L}^{\text {hi }} \mathrm{CD} 8{ }^{+} \mathrm{T}_{\mathrm{SCM}^{-}}$-like cells (Supplementary Fig. 13a). The number of $\mathrm{iT}_{\mathrm{SCM}}$ cells generated by OP9-DL1 coculture was much higher than that of TWS119-induced $\mathrm{T}_{\mathrm{SCM}}$-like cells from the same number of naive CD8 ${ }^{+} \mathrm{T}$ cells (Supplementary Fig. 13b). This is probably due to a strong anti-proliferative effect of TWS119. When we injected the same number of OVA-specific $i \mathrm{~T}_{\mathrm{SCM}}$ cells or TWS119-induced $\mathrm{T}_{\mathrm{SCM}}$-like cells into E.G7-OVA-bearing mice, both types of $\mathrm{T}$ cells showed similar antitumour effects. These results suggest that the antitumour efficacy of $\mathrm{iT}_{\mathrm{SCM}}$ cells is 
a
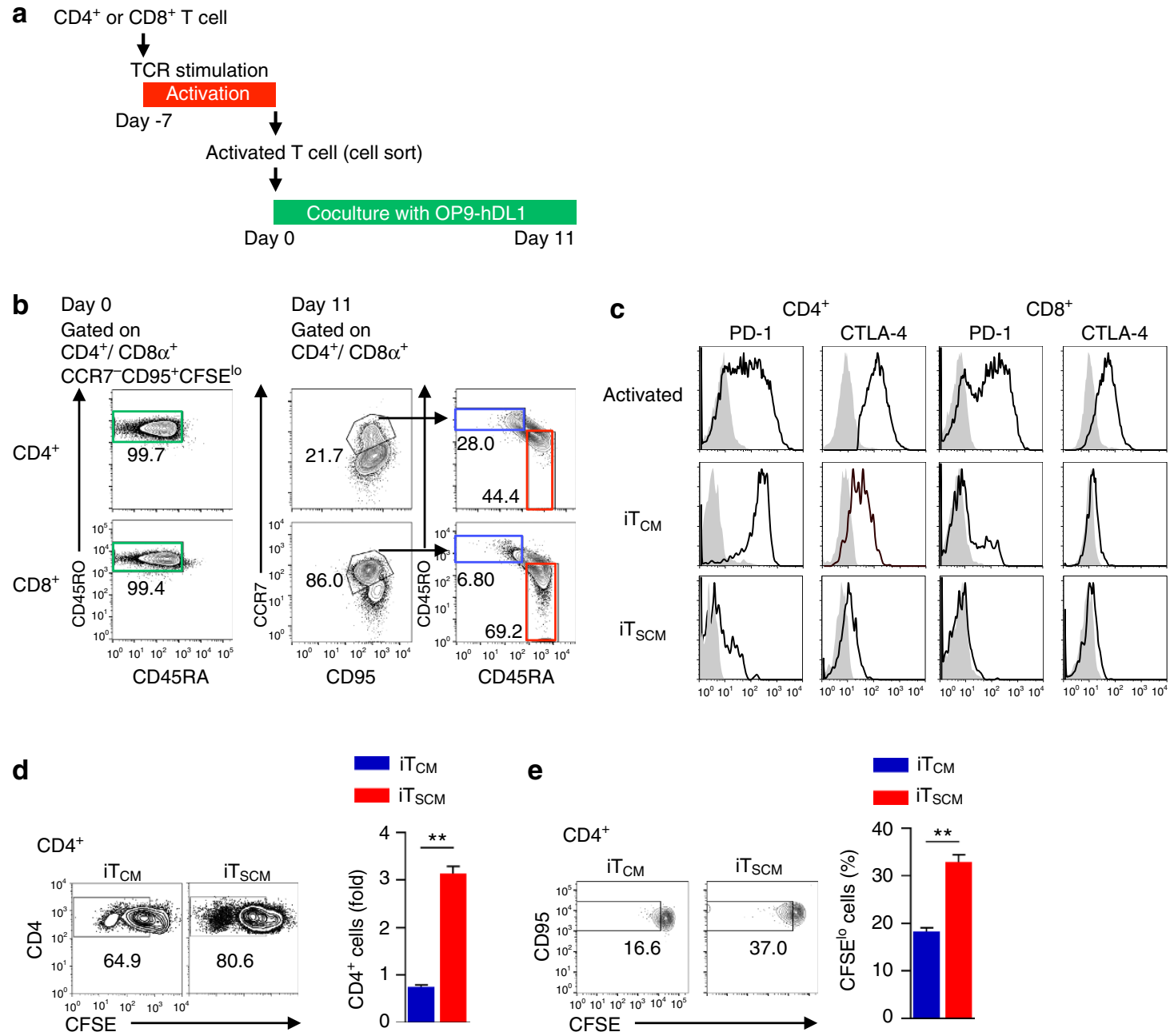

e
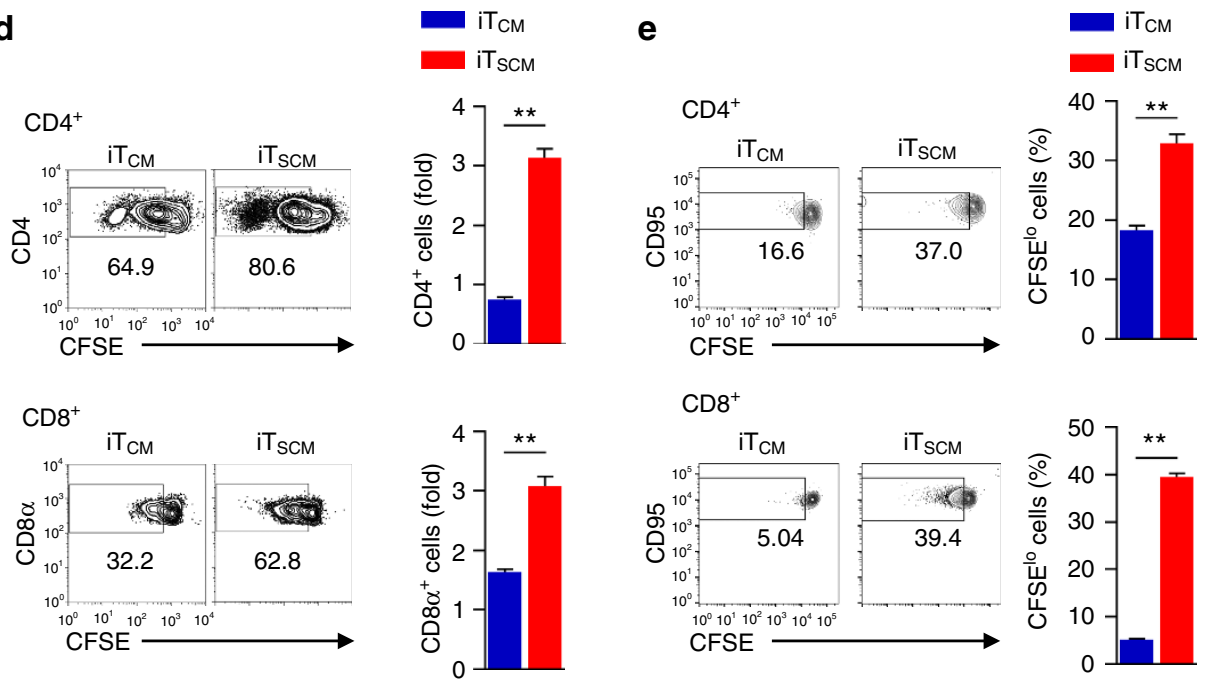

Figure 7 | Generation of human $\mathbf{C D 4}{ }^{+}$and $\mathbf{C D 8}{ }^{+} \mathbf{i T}_{\mathbf{S C M}}$ cells. (a) Scheme for inducing antigen-specific human $\mathrm{CD} 4^{+}$and $_{\mathrm{CD}} 8^{+} \mathrm{iT}_{\mathrm{SCM}}$ cells. $\mathrm{CD} 4{ }^{+}$or $\mathrm{CD}^{+}{ }^{+} \mathrm{T}$ cells from PBMC were activated with EBV-transformed autologous LCL then cocultured with OP9-hDL1 cells. (b) Generating EBV-specific CD4 ${ }^{+}$ and $\mathrm{CD}^{+}{ }^{+} \mathrm{iT}_{\mathrm{SCM}}$ cells. CFSE-labelled peripheral $\mathrm{CD} 4^{+}$or $\mathrm{CD}^{+}$memory $\left(\mathrm{CD} 45 \mathrm{RA}{ }^{-} \mathrm{CD} 45 \mathrm{RO}{ }^{+} \mathrm{CCR} 7 \pm \mathrm{CD} 95^{+}\right) \mathrm{T}_{\text {cells }}$ were cocultured with $40 \mathrm{~Gy}$ irradiated EBV-transformed autologous LCL for seven days. EBV-specific activated T cells (CD45RA $\left.{ }^{-} \mathrm{CD} 45 \mathrm{RO}{ }^{+} \mathrm{CCR} 7^{-} \mathrm{CD} 95^{+} \mathrm{CFSE}{ }^{\circ}\right)(\mathrm{Day} 0)$ were sorted, and then cocultured with OP9-hDL1 cells for 11 days. Cells on Day 0 and 11 were subjected to flow cytometry analysis. CD45RA/CD45RO profiles of activated T cells on Day 0, CCR7/CD95 profiles on Day 11 after coculture with OP9-hDL1, and CD45RA/CD45RO profiles of the CCR7 ${ }^{+}$CD95 ${ }^{+}$fraction are shown. Representative data of three-independent experiments are shown. (c) Expression of PD-1 and CTLA-4 on human activated T, iT ${ }_{C M}$ and iT $T_{S C M}$ cells. Representative data of three-independent experiments are shown. (d) Recall responses to EBV. CFSE-labelled EBV-specific $\mathrm{iT}_{\mathrm{CM}}$ and $\mathrm{iT}_{\mathrm{SCM}}$ cells $\left(5 \times 10^{4}\right)$ were cocultured with autologous LCL for $60 \mathrm{~h}$. The percentages of CFSE ${ }^{\text {lo }}$ cells are shown (left). The bar graphs show the fold increase of recovered T cells ( $n=3$ per group) (right). (e) Proliferative responses to IL-7. iT $\mathrm{CM}$ and iT SCM cells were cultured in the presence of IL-7 for seven days. The percentages of CFSE ${ }^{\text {lo }}$ cells are shown (left). The bar graphs show the fraction of CFSE ${ }^{l o}$ T cells ( $n=3$ per group) (right). ${ }^{\star \star} P<0.01$ (Student's $t$-test). Data are representative of independent experiments using human samples provided by three healthy donors. Error bars show s.e.m.

equivalent to that of TWS119-induced $\mathrm{T}_{\mathrm{SCM}}$-like cells; however, coculture with OP9-DL1 is advantageous in generating a larger number of antigen-specific $\mathrm{T}_{\mathrm{SCM}}$-like cells.

Generation of $\mathbf{i T}_{\mathbf{S C M}}$ cells from human $\mathbf{T}$ cells. We then attempted to generate antigen-specific $\mathrm{iT}_{\mathrm{SCM}}$ cells from human peripheral blood $\mathrm{T}$ cells by coculturing with human DLL1expressing OP9 (OP9-hDL1) cells. $\mathrm{CD}^{+}$and $\mathrm{CD}^{+}$memory $\mathrm{T}$ cells were cocultured with autologous Epstein Barr virus (EBV)-transformed lymphoblastoid cell lines (LCLs) ${ }^{25,26}$. Seven days later, EBV-specific activated $\mathrm{T}$ cells were sorted as $\mathrm{CD} 45 \mathrm{RA}^{-} \mathrm{CD} 45 \mathrm{RO}^{+} \mathrm{CCR}^{-}{ }^{-} \mathrm{CD}{ }^{+}{ }^{+} \mathrm{CFSE}^{\mathrm{lo}}$ cells (Supplementary Fig. 14a) and then cocultured with OP9-hDL1 cells for 
11 days (Fig. 7a). Coculturing with OP9-hDL1 cells induced $\mathrm{CD}_{45 \mathrm{RA}}{ }^{+} \mathrm{CD} 45 \mathrm{RO}^{-} \mathrm{CCR}^{+}{ }^{+} \mathrm{CD} 5^{+} \mathrm{T}_{\mathrm{SCM}}$-like cells and $\mathrm{CD} 4 \mathrm{RA}^{-}{ }^{-} \mathrm{CD} 45 \mathrm{RO}^{+}{ }^{-\mathrm{CCR} 7}{ }^{+} \mathrm{CD}^{+}{ }^{+} \mathrm{iT}_{\mathrm{CM}}$ cells from both EBV-specific $\mathrm{CD}^{+}{ }^{+}$and $\mathrm{CD} 8{ }^{+} \mathrm{T}$ cells; we defined these cells as human $\mathrm{iT}_{\mathrm{SCM}}$ and $\mathrm{iT}_{\mathrm{CM}}$ cells, respectively (Fig. $7 \mathrm{~b}$ ). To achieve substantial conversion to $\mathrm{T}_{\mathrm{SCM}}$ phenotypes, over 11 days coculture with OP9-hDL1 cells was necessary (Supplementary Fig. 14b). Conversion rate was varied among three independent donors (Supplementary Fig. 14b and c). Conversion efficiency from EBV-specific activated human $\mathrm{T}$ cells to $\mathrm{iT}_{\mathrm{SCM}}$ is $5-9 \%$ for $\mathrm{CD}^{+} \mathrm{T}$ cells and $12-66 \%$ for $\mathrm{CD} 8{ }^{+} \mathrm{T}$ cells depending on the donors. IL-15 is well known as a cytokine associated with memory cell proliferation and homoeostasis. Coculturing with OP9-hDL1 cells in the presence of IL-15 strongly reduced the efficiency of $\mathrm{iT}_{\mathrm{SCM}}$ cell induction (Supplementary Fig. 14d). We also successfully induced melanoma antigen Mart-1-specific $\mathrm{CD}^{+}{ }^{+} \mathrm{T}_{\mathrm{SCM}}$ cells from healthy donors (Supplementary Fig. 15a). Coculturing with OP9-hDL1 cells induced downregulation of PD-1 and CTLA-4 expressions on both EBV-specific CD4 ${ }^{+}$ and $\mathrm{CD}^{+}{ }^{+} \mathrm{T}$ cells. PD-1 and CTLA-4 expression levels on EBV-specific $\mathrm{iT}_{\mathrm{SCM}}$ cells were much lower than those on EBV-specific $\mathrm{iT}_{\mathrm{CM}}$ cells (Fig. 7c). To investigate the EBV-specific recall response, we cocultured EBV-specific CD4 ${ }^{+}$ and $\mathrm{CD} 8{ }^{+}{ }^{i T_{C M}}$ and ${ }^{2} T_{S C M}$ cells with autologous LCLs for $6 \mathrm{~h}$. We found that $\mathrm{EBV}$-specific $\mathrm{CD} 4{ }^{+} \mathrm{iT}_{\mathrm{SCM}}$ cells generated a higher percentage of IFN- $\gamma^{+} \mathrm{CD}_{40 \mathrm{~L}}{ }^{+}$cells than the $\mathrm{CD} 4{ }^{+}$ $\mathrm{iT}_{\mathrm{CM}}$ cells did. On the other hand, EBV-specific $\mathrm{CD} 8^{+} \mathrm{iT}_{\mathrm{SCM}}$ cells produced less perforin- and/or granzymeB-producing cells than the $\mathrm{CD}^{+}{ }^{+} \mathrm{iT}_{\mathrm{CM}}$ cells did, resulting in sufficient but lower killing activity against autologous LCLs (Supplementary Fig. $15 \mathrm{~b}, \mathrm{c})$. However, $60 \mathrm{~h}$ after coculture, EBV-specific $\mathrm{CD} 8^{+}$, as well as $\mathrm{CD}^{+}{ }^{+} \mathrm{iT}_{\mathrm{SCM}}$ cells divided better than $\mathrm{CD} 8^{+}$and $\mathrm{CD}^{+}{ }^{+} \mathrm{iT}_{\mathrm{CM}}$ cells did. Consequently, both of the EBV-specific $i T_{S C M}$ cells recovered greater numbers of the cells than the $\mathrm{iT}_{\mathrm{CM}}$ cells did (Fig. $7 \mathrm{~d}$ ). In addition, $\mathrm{CD}^{+}$and $\mathrm{CD} 8^{+} \mathrm{iT}_{\mathrm{SCM}}$ cells divided more rapidly in the presence of a homoeostatic cytokine IL-7 than $\mathrm{CD} 4^{+}$and $\mathrm{CD} 8^{+}{ }^{-\mathrm{TT}_{\mathrm{CM}}}$ cells did (Fig. 7e). These results indicated that the Notch signalling generated antigen-specific $\mathrm{iT}_{\mathrm{SCM}}$ cells from human peripheral blood $\mathrm{CD} 4^{+}$and $\mathrm{CD} 8{ }^{+} \mathrm{T}$ cells.

Comparison of human $\mathrm{iT}_{\mathrm{SCM}}$ cells with other memory $\mathrm{T}$ cells. Last, we investigated the ontology of human $\mathrm{iT}_{\mathrm{SCM}}$ cells. We compared gene expression profiles of human $\mathrm{CD} 8{ }^{+}{ }^{\mathrm{iT}} \mathrm{SCM}$ cells, $\mathrm{T}_{\mathrm{SCM}}$ cells reported by Gattinoni et al., and $\mathrm{T}_{\mathrm{MNP}}$ cells reported by Pulko et al., which were currently known as memory $\mathrm{T}$ cell subsets with a naive $\mathrm{T}$ cell phenotype $\mathrm{e}^{10,11,24}$. The data on those memory $\mathrm{T}$ cells were obtained from a public database (GSE2331, GSE80306, GSE68003). For this comparison, we focused on 1771 transcripts found to be differentially expressed among naive, $\mathrm{T}_{\mathrm{CM}}, \mathrm{T}_{\mathrm{EM}}, \mathrm{T}_{\mathrm{SCM}}, \mathrm{T}_{\mathrm{MNP}}$ and TWS119-induced $\mathrm{T}_{\mathrm{SCM}}$ cells generated in vitro (called ' $\mathrm{T}_{\mathrm{SCM}^{-}}$-enriched' in ref. 24) and our Notch-induced $\mathrm{iT}_{\mathrm{SCM}}$ cells. Clustering analysis revealed that $\mathrm{iT}_{\mathrm{SCM}}$ cells were most closely related to TWS119-induced $\mathrm{T}_{\mathrm{SCM}}$ cells (Supplementary Fig. 16a). Pathway analysis of 1771 selected genes also revealed that pathway profiles of $\mathrm{iT}_{\mathrm{SCM}}$ cell were similar to those of TWS119-induced $\mathrm{T}_{\mathrm{SCM}}$ cells. Importantly, the gene expression levels of pathways for oxidative phosphorylation, cell growth and interferon response were higher both in TWS119-induced $\mathrm{T}_{\mathrm{SCM}}$ and Notch-induced $\mathrm{iT}_{\mathrm{SCM}}$ cells than in other memory $\mathrm{T}$ cell subsets (Supplementary Fig. 16b). PC analysis also revealed that Notch-induced $\mathrm{iT}_{\mathrm{SCM}}$ was positioned most closely to TWS119-induced $\mathrm{T}_{\mathrm{SCM}}$, but was distantly related to in vivo $\mathrm{T}_{\mathrm{SCM}}$ and $\mathrm{T}_{\mathrm{MNP}}$ cells (Supplementary Fig.16c).

\section{Discussion}

The conversion of the cellular fate of differentiated cells is a current challenge facing modern cell biology. The strategy of converting from 'exhausted' $T$ cells into 'vigorous' $T$ cells is important for adoptive $\mathrm{T}$-cell immunotherapy because the quality of $\mathrm{T}$ cells decides the improvement in patient outcomes. Recent studies have challenged the rejuvenation of differentiated $\mathrm{T}$ cell by various approaches. Refreshment of T cells via iPS cells derived from antigen-specific $\mathrm{T}$ cells ( $\mathrm{T}-\mathrm{iPS}$ cells) is promising ${ }^{5,6}$. However, a significant length of time is needed to establish iPS cells, and the efficiency of generating T cells from iPS cells is still not high. Newly identified memory T cell subsets with naive markers, $T_{S C M}$ and $T_{M N P}$ cells possess stronger proliferative potential than naive and other memory cells do. The generation of $\mathrm{T}_{\mathrm{SCM}}$ cells is a very effective strategy for target-specific $\mathrm{T}$ cell therapy ${ }^{10}$. Transplantation of quasi naive $\mathrm{T}$ cells could provide the breakthrough in developing a more effective immunotherapy.

In this study, we propose a novel strategy of generating Notch signalling-induced $\mathrm{T}_{\mathrm{SCM}}$ cells ( $\mathrm{iT}_{\mathrm{SCM}}$ cells) from activated $\mathrm{T}$ cells by coculturing with OP9 cells expressing a Notch ligand. $\mathrm{iT}_{\mathrm{SCM}}$ cells possessed longevity, the potential to produce a large number of effector cells and exhibited potent antitumour activities. Notably, the combinational transplantation of $\mathrm{CD}^{+}$and $\mathrm{CD}^{+}{ }^{-} \mathrm{iT}_{\mathrm{SCM}}$ cells achieved approximately $40 \%$ of a complete remission state in tumour-bearing mice. In addition to the method of inducing $\mathrm{T}_{\mathrm{SCM}}$ cells by Wnt activators, our method can generate $\mathrm{T}_{\mathrm{SCM}}$-like cells from conventional memory $\mathrm{T}$ cells by Notch signalling. This method has an advantage compared with Wnt activators since $\mathrm{iT}_{\mathrm{SCM}}$ cells can be converted from antigen-specific memory $\mathrm{T}$ cells, thus TCR gene transduction is not necessary.

Gene expression profile analysis revealed that our Notchinduced $\mathrm{iT}_{\mathrm{SCM}}$ cells were most similar to TWS119-induced $\mathrm{T}_{\mathrm{SCM}}$ cells generated in vitro. These two in vitro-generated $\mathrm{T}_{\mathrm{SCM}}$-like cells were distantly related to in vivo $\mathrm{T}_{\mathrm{SCM}}$ and $\mathrm{T}_{\mathrm{MNP}}$ cells. Our data suggested that Notch-induced $\mathrm{iT}_{\mathrm{SCM}}$ cells were very different from other memory $\mathrm{T}$ cell subsets including in vivo-derived $\mathrm{T}_{\mathrm{CM}}$, $\mathrm{T}_{\mathrm{EM}}, \mathrm{T}_{\mathrm{SCM}}$ and $\mathrm{T}_{\mathrm{MNP}}$ cells. PC analysis suggests that TWS119induced $\mathrm{T}_{\mathrm{SCM}}$ cells are also slightly distinct from in vivo memory $\mathrm{T}$ cells. Thus, in vitro generated $\mathrm{T}_{\mathrm{SCM}}$-like cells induced by Notch or Wnt signals have a specific character acquired during in vitro stimulation. Nevertheless, in vitro generated $\mathrm{T}_{\mathrm{SCM}^{-}}$-like cells were extremely useful for $\mathrm{T}$ cell based adoptive cancer immunotherapy. Although two in vitro generated $\mathrm{T}_{\mathrm{SCM}}$-like cells possessed a similar antitumour ability, a significantly greater number of $\mathrm{T}_{\mathrm{SCM}}$-like cells can be obtained by coculture with Notch-ligand expressing stroma cells compared with TWS119 treatment. Therefore, our method may have another advantage for adoptive immunotherapy in terms of the cell number.

Notch signalling has been shown to be closely linked to various immune responses, especially the formation and maintenance of memory $\mathrm{T}$ cells. A recent paper suggested that Notch signalling promotes the differentiation of terminal effector cells in the contracting phase; therefore, the lack of Notch1 and Notch2 expanded the mature memory $\mathrm{T}$ cell pool $^{27}$. In contrast, an attribution of HIF- $1 \alpha$ and Notch to long-term survival of effector memory Th17 cells ${ }^{28}$, Notch signalling has been shown to be essential for the survival of conventional memory $\mathrm{T}$ cells by increasing glucose uptake ${ }^{18}$. Aberrant Notch signalling in $\mathrm{T}$ cell acute lymphoblastic leukaemia has been shown to induce activation of the PTEN-PI3 kinase pathway and the downmodulation of p53 (refs 21,29). These studies suggested that Notch signalling played divergent roles in the contraction and memory phase of the $\mathrm{T}$ cell response. Our studies indicate that Notch signalling redirects differentiation from memory precursor-like activated $\mathrm{T}$ cells to $\mathrm{iT}_{\mathrm{SCM}}$ cells. It is notable that 
T cells are generated from iPS cells by the coculture with the same OP9-DL1 cells ${ }^{5,6}$.

PD-1 and CTLA-4 have been shown to be a marker of exhausted $\mathrm{T}$ cells and are now important targets of antitumour therapy ${ }^{30-32}$. A high expression of PD-1 and CTLA-4 in activated $\mathrm{T}$ cells is restored to levels similar to those of naive $\mathrm{T}$ cells through $\mathrm{iT}_{\mathrm{SCM}}$ cell induction. Low levels of these inhibitory receptors may explain a rapid proliferative response to antigens and the stronger antitumour potential of $\mathrm{iT}_{\mathrm{SCM}}$ cells. Expression of PD- 1 and CTLA- 4 may not be down-regulated by Notch, since we observed similar reduction of PD- 1 and CTLA- 4 in T cells after coculture with OP9 not expressing Delta-like 1. The mechanism of reduction of PD-1 and CTLA-4 needs to be clarified. In addition, p53 has also been reported to be a suppressor of $\mathrm{T}$ cell proliferation ${ }^{23}$. A lack of p53 inhibited activation-induced cell death and increased proliferation, the expression of stemness gene signature and antitumour activities $^{33,34}$. Indeed, p53 expression in $\mathrm{iT}_{\mathrm{SCM}}$ cells was lower than in $\mathrm{iT}_{\mathrm{CM}}$ cells after TCR stimulation. Thus, lower p53 expression may allow $\mathrm{iT}_{\mathrm{SCM}}$ cells to evade apoptosis and cell cycle arrest, and acquire antitumour activity, unlike $\mathrm{iT}_{\mathrm{CM}}$ cells. Clarifying the mechanism of downregulation of $\mathrm{p} 53$ in $\mathrm{iT}_{\mathrm{SCM}}$ cells will provide a new strategy for breaking immune checkpoint mechanisms.

In conclusion, although the mechanism underlying the induction of $\mathrm{iT}_{\mathrm{SCM}}$ cells by Notch signalling remained to be clarified, $\mathrm{iT}_{\mathrm{SCM}}$ cells should also prove useful in long-term potent vaccination against not only cancer but also severe infectious diseases. Our findings will pave the way to the establishment of highly efficient antigen-specific $\mathrm{T}$ cell therapy applicable for various clinical settings.

\section{Methods}

Mice. Six- to eight-weeks-old male C57BL/6 mice were purchased from Tokyo Laboratory Animals Science (Tokyo, Japan) and Japan SLC (Shizuoka, Japan). IFN- $\gamma$ Venus reporter mice were generated by introducing the transgenic BAC gene, which carried the IRES-Venus cassette in the Ifng exon 4. IL-4 human CD2 reporter mice were generated by introducing the transgenic BAC gene. IL-17A eGFP reporter mice (No. 018472) were ordered from Jackson Labs (Bar Harbor, ME, USA). OT-I-TCR-transgenic ${ }^{35}$, OT-II-TCR-transgenic ${ }^{36}$, and Rag2 ${ }^{-1}$ (ref. 37) mice were described previously. All mice were kept in specific pathogenfree facilities at Keio University. Animal experiments were performed in strict accordance with the recommendations in the Guidelines for Proper Conduct of the Animal Experiments of the Science Council of Japan. All experiments using mice were approved by the Animal Ethics Committee of Keio University and were performed according to the Animal Ethics Committee's guidelines.

Antibodies and reagents. Fluorophore-conjugated or biotinylated monoclonal anti-mouse CD3ع (145-2C11), anti-mouse CD4 (RM4-5), anti-mouse CD8 $\alpha$ (53-6.7), anti-human/mouse CD11b (M1/70), anti-mouse CD11c (N418), anti-mouse CD19 (6D5), anti-human/mouse CD45R (RA3-6B2), anti-mouse CD49b (DX5), anti-mouse TER-119 (TER-119), anti-mouse TCR $\gamma \delta$ (GL3), anti-mouse IFN- $\gamma$ (XMG1.2), anti-mouse IL-4 (11B11), anti-mouse/Rat IL-17A (eBio17B7), anti-mouse/Rat Foxp3 (FJK-16s), anti-mouse/human CD44 (IM7), anti-mouse CD62L (MEL-14), anti-mouse CD45.1 (A20), anti-mouse CD45.2 (104), anti-mouse Notch1 (HMN1-12), anti-mouse Notch2 (HMN2-35), anti-mouse Notch3 (HMN3-133), anti-mouse KLRG1 (2F1), anti-mouse Ly-6C (HK1.4), anti-mouse CD127 (A7R34), anti-mouse CD25 (PC61.5), anti-mouse CD154 (MR1), anti-mouse/Rat CD278 (C398.4A), anti-mouse CD279 (J43), anti-mouse CD152 (UC10-4B9), anti-mouse CD197 (4B12), anti-mouse CD122 (TM- $\beta 1$ ), anti-mouse Ly-6A/E (E13-161.7), anti-mouse Bcl-2 (BCL/10C4), anti-Human/Mouse phospho-AKT (S473) (SDRNR), anti-human CD2 (RPA2.10), anti-human CD4 (RPA-T4), anti-human CD8 $\alpha$ (HIT8a), anti-human CD45RA (HI100), anti-human CD45RO (UCHL1), anti-human CCR7 (G043H7), anti-human CD95 (DX2), anti-human CD154 (24-31), anti-human CD279 (PD-1) (EH12.2H7), anti-human CD152 (CTLA-4) (L3D10), and anti-human IFN- $\gamma$ (B27) were purchased from eBioscience (San Diego, CA, USA) or Bio Legend (San Diego, CA, USA). APC-conjugated Ab specific for mouse CXCR3 (220803) and Recombinant Mouse DL1 FC Chimera Protein were purchased from R\&D systems (Minneapolis, MN, USA). PE-conjugated Ab specific for human CD8 $\beta$ (2ST8.5H7) was purchased from Beckman Coulter (Brea, CA, USA). Alexa Fluor 647-conjugated Ab specific for mouse phospho-Stat5 (Y694) (47/Stat5(pY694)) was purchased from BD Biosciences (Franklin Lakes, US-NJ, USA). Alexa Fluor 647-conjugated mouse p53 was purchased from Cell Signaling Technology (Danvers, MA 01923, USA). HLA-A2 Mart-1 (Alexa Fluor 647-labelled HLA-A-02:01/ELAGIGILTV) and HLA-A2 PSA (Alexa Fluor 647-labelled HLA-A-02:01/FLTPKKLQCV) tetramers were obtained from the NIH tetramer core facility at Emory University. $\gamma$-secretase inhibitor DAPT was purchased from Cayman Chemical (Ann Arbor, MN, USA). ABCG2 inhibitor FTC was purchased from Bioaustralis (Smithfield, NSW, Australia). FK506 was purchased from Sigma-Aldrich (St. Louis, MO, USA). OVA peptides $\left(\mathrm{OVA}_{257-264}\right.$ and $\left.\mathrm{OVA}_{323-339}\right)$ were purchased from Synpeptide (Shanghai, China). A CellTrace ${ }^{\mathrm{TM}}$ CFSE Cell Proliferation Kit (\#C34554), Propidium iodide (\#P3566), Vybrant DyeCycle Violet Stain (DCV, \# V35003), and LIVE/DEAD Viability/Cytotoxicity kits for mammalian cells containing calcein AM and ethidium homodimer-1 (\#L3224) were purchased from Thermo Fisher Scientific (Waltham, MA, USA). An AnnexinV-FITC Apoptosis kit (\#K101-25) was purchased from BioVision (Milpitas, CA, USA).

Cell lines. OP9 cells were a kind gift from Dr. Hiroshi Kawamoto (Kyoto University). Control OP9 feeder cells, mouse Delta-like1 expressing-OP9 cells (OP9-DL1), and human Delta-like 1 expressing-OP9 cells (OP9-hDL1) were cultured in alpha MEM (Thermo Fisher Scientific) supplemented with 20\% FBS and $1 \%$ penicillin/streptomycin. E.G7-OVA cells were purchased from ATCC (Manassas, VA USA). E.G7-OVA cells were cultured in complete RPMI 1640 (Thermo Fisher Scientific) supplemented with $10 \%$ FBS, $1 \%$ penicillin/streptomycin, and $400 \mathrm{~g} \mathrm{ml}^{-1}$ G418 (Nacalai Tesque, Kyoto, Japan). Lymphoblastoid cell lines (LCLs) were established from peripheral blood mononuclear cells (PBMCs) provided from three healthy donors, as described in previous studies ${ }^{25,26}$ PBMCs were cultured in complete RPMI medium with 10\% FBS, Epstein-Barr virus (EBV) solution, and 20 nM FK506 for more than one month.

Mouse primary T cell and CD11c ${ }^{+}$DC isolation. Mouse CD4 ${ }^{+} \mathrm{T}$ cells were isolated from spleen and lymph nodes using a mouse CD4 ${ }^{+} \mathrm{T}$ cell isolation kit (\#130-104-454) and AutoMACS Pro (Miltenyi Biotec, Bergisch Gladbach, Germany). Isolated $\mathrm{CD} 4{ }^{+} \mathrm{T}$ cells were stained with fluorophore-conjugated anti-CD4/CD8 $\alpha$, and CD44, CD62L Abs and naive CD4 ${ }^{+} \mathrm{T}$ cells were purified by gating on $\mathrm{CD} 4{ }^{+} / \mathrm{CD} 8 \alpha^{+} \mathrm{CD} 25^{-} \mathrm{CD} 44^{\mathrm{lo}} \mathrm{CD} 62 \mathrm{~L}^{\text {hi }}$ cells using a cell sorter.

Mouse $\mathrm{CD} 8{ }^{+} \mathrm{T}$ cells were isolated from spleen and lymph nodes by depletion of non-CD8 $\alpha^{+}$T cells using biotinylated Abs against mouse CD4, CD19, B220, CD11b, CD11c, CD49b, TER-119 and TCR $\gamma \delta$ in combination with streptavidin MicroBeads using AutoMACS Pro (Miltenyi Biotec). Isolated CD8 ${ }^{+} \mathrm{T}$ cells were stained with fluorophore-conjugated anti-CD8 $\alpha$, and CD44, CD62L Abs, and naive $\mathrm{CD} 8{ }^{+} \mathrm{T}$ cells were purified by gating on $\mathrm{CD} 8 \alpha{ }^{+} \mathrm{CD} 44^{\mathrm{lo}} \mathrm{CD} 62 \mathrm{~L}^{\text {hi }}$ using a cell sorter. Splenic CD11 $c^{+}$dendritic cells (DCs) were positively selected using CD11c MicroBeads, mouse (\#130-108-338, Miltenyi Biotec) from splenocytes of 6- to 8-week-old wild-type mice.

Activation of primary mouse $\mathrm{CD4}^{+}$and $\mathrm{CD8}^{+} \mathbf{T}$ cells in vitro. Wild-type mouse naive $\mathrm{CD} 4{ }^{+} \mathrm{T}$ cells were stimulated with soluble anti-CD28 Ab (57.31; $\left.2 \mu \mathrm{g} \mathrm{ml}^{-1}\right)$ and plate-coated anti-CD3\& Ab $\left(145-2 \mathrm{C} 11 ; 5 \mu \mathrm{g} \mathrm{ml}^{-1}\right)$ under each set of Th differentiation conditions. Th conditions in this study were as follows: Th1 conditions: IL-12 (PeproTech, Rocky Hill, NJ; $10 \mathrm{ng} \mathrm{ml}^{-1}$ ) and anti-IL-4 Ab (11B11; $\left.2 \mu \mathrm{g} \mathrm{ml}^{-1}\right)$; Th2 conditions: IL-4 (PeproTech; $20 \mathrm{ng} \mathrm{ml}^{-1}$ ) and anti-IFN- $\gamma$ Ab (R4-6A2; $2 \mu \mathrm{g} \mathrm{ml}^{-1}$ ); Th17 (TGF- $\beta+$ IL-6) conditions: TGF- $\beta$ (Bio Legend; $2 \mathrm{ng} \mathrm{ml}^{-1}$ ), IL-6 (PeproTech; $30 \mathrm{ng} \mathrm{ml}^{-1}$ ), anti-IFN- $\gamma$ Ab (R4-6A2; $2 \mu \mathrm{g} \mathrm{ml}^{-1}$ ), anti-IL-4 Ab (11B11, $2 \mu \mathrm{g} \mathrm{ml}^{-1}$ ), and anti-IL-2 Ab (JES6-1A12, $2 \mu \mathrm{g} \mathrm{ml}^{-1}$ ); Th17 (IL-1 $\beta$ + IL-6 + IL-23) conditions: IL-1 $\beta$ (PeproTech; $20 \mathrm{ng} \mathrm{ml}^{-1}$ ), IL-6 (PeproTech; $30 \mathrm{ng} \mathrm{ml}^{-1}$ ), IL-23 (PeproTech; $20 \mathrm{ng} \mathrm{ml}^{-1}$ ), anti-IFN- $\gamma \mathrm{Ab}$ (R4-6A2; $2 \mu \mathrm{g} \mathrm{ml}^{-1}$ ), anti-IL-4 Ab (11B11, $2 \mu \mathrm{g} \mathrm{ml}^{-1}$ ), and anti-IL-2 Ab (JES6-1A12, $2 \mu \mathrm{g} \mathrm{ml}^{-1}$ ); and Treg conditions: TGF- $\beta$ (Bio Legend; $2 \mathrm{ng} \mathrm{ml}^{-1}$ ), IL-2 (PeproTech; $\left.20 \mathrm{ng} \mathrm{ml}^{-1}\right)$, anti-IFN- $\gamma \mathrm{Ab}\left(2 \mu \mathrm{g} \mathrm{ml}^{-1}\right)$ and anti-IL-4 Ab (11B11, $2 \mu \mathrm{g} \mathrm{ml}^{-1}$ ).

Rag2 $^{-1}-$ OT-II and OT-II naive $\mathrm{CD}^{+}$T cells were primed with $10 \mu \mathrm{g} \mathrm{ml}^{-1}$ $\mathrm{OVA}_{323-339}$ peptide pulsed splenic CD11c ${ }^{+}$DCs under Th1 conditions, and OT-I naive CD8 ${ }^{+} \mathrm{T}$ cells were primed with $10 \mu \mathrm{g} \mathrm{ml}^{-1} \mathrm{OVA}_{257-264}$ pulsed splenic $\mathrm{CD}_{11 \mathrm{c}}{ }^{+}$DCs with $20 \mathrm{ng} \mathrm{ml}^{-1} \mathrm{IL}-2$.

All cultures were grown in RPMI 1640 (Invitrogen) supplemented with $10 \%$ FBS, $1 \%$ penicillin/streptomycin, $100 \mathrm{nM}$ nonessential amino acids, $2 \mathrm{mM}$ glutamine and $0.05 \mathrm{mM} \beta$-mercaptoethanol.

Human T cell culture. Human PBMCs were prepared by specific gravity centrifugal methods from peripheral blood. Peripheral blood was provided by three healthy donors who were EBV-seropositive (VCA-IgG $[+]$, EBNA $[+]$ ). We prepared $\mathrm{CD} 8{ }^{+} \mathrm{T}$ cells from PBMCs with depletion of non-CD8 $\alpha^{+} \mathrm{T}$ cells using a human $\mathrm{CD}^{+} \mathrm{T}$ cell isolation kit (\#130-096-495, Miltenyi Biotec). To induce EBV-specific CD8 ${ }^{+} \mathrm{T}$ cells, $\mathrm{CD} 8{ }^{+} \mathrm{T}$ cells were labelled with CFSE and were subsequently cocultured with $40 \mathrm{~Gy}$-irradiated autologous LCLs for seven days. To induce Flu-specific CD8 ${ }^{+} \mathrm{T}$ cells, we labelled PBMC with CFSE and subsequently cultured them in the presence of heat-killed influenza A virus (PR8 line). We prepared CD4 ${ }^{+} \mathrm{T}$ cells from PBMCs with depletion of non-CD4 ${ }^{+}$ $\mathrm{T}$ cells through human CD4 ${ }^{+} \mathrm{T}$ cell isolation kit (\#130-096-533, Miltenyi Biotec). 
To induce EBV-specific CD4 ${ }^{+} \mathrm{T}$ cells, $\mathrm{CD} 4^{+} \mathrm{T}$ cells were labelled with CFSE and were subsequently cocultured with $40 \mathrm{~Gy}$-irradiated autologous LCLs for 7 days.This study was approved by the Ethics Committee of Keio University.

OP9-DL1 or OP9-hDL1 cell coculture system. Mouse and human T cells were activated using the methods mentioned above. To activate Notch signalling, activated T cells were cocultured with Notch ligand-expressing OP9 feeder cells, OP9-DL1 cells for mouse T cells and OP9-hDL1 cells for human T cells. We cultured mouse T cells and OP9-DL1 cells with mouse IL-7 (PeproTech; $10 \mathrm{ng} \mathrm{ml}^{-1}$ ), an anti-mouse IFN- $\gamma$ antibody (R4-6A2; $2 \mu \mathrm{g} \mathrm{ml}^{-1}$ ), in alpha MEM for 11-12 days. Human T cells and OP9-hDL1 cells were cocultured with human IL-7 (PeproTech; $10 \mathrm{ng} \mathrm{ml}^{-1}$ ), an anti-human IFN- $\gamma$ antibody (Bio Legend, B27; $2 \mu \mathrm{g} \mathrm{ml}^{-1}$ ), in alpha MEM for 11 days.

Flow cytometry and cell sorting. Antibody dilution factors are 1:400 for antibodies purchased from BioLegend and eBioscience, and 1:100 for antibodies purchased from R\&D systems, Beckman Coulter, BD Biosciences and Cell Signaling Technology and for HLA-A2 tetramers. For IFN- $\gamma$, IL-4, IL-17A and Foxp3 intracellular staining, cells were stimulated for $6 \mathrm{~h}$ in a complete medium with PMA (50 $\mathrm{n} \mathrm{ml}^{-1}$ ) and ionomycin (500 $\mathrm{ng} \mathrm{ml}^{-1}$; both from Sigma-Aldrich) in the presence of brefeldin A (eBioscience). Surface staining was then performed in the presence of $\mathrm{Fc}$-blocking antibodies (2.4G2), followed by intracellular staining for anti-IFN- $\gamma$, IL-4, IL-17A and Foxp3 antibodies with Foxp3/transcription factor fixation/permeabilization concentrate and diluent (\#00-5521-00, eBioscience), according to the manufacturer's instructions. For pStat5 and pAkt staining, cells were fixed and permeabilized with $4 \%$ paraformaldehyde and ice-cold $90 \%$ methanol and incubated with antibodies for $1 \mathrm{~h}$ at room temperature. For Bcl-2 and p53 staining, cells were fixed and permeabilized with Foxp3/transcription factor fixation/permeabilization concentrate and diluent (eBioscience), according to the manufacturer's instructions. We performed flow cytometry acquisition on a FACS Canto II cytometer (BD Biosciences, San Jose, CA, USA) and analysed the data using FlowJo software (Tree Star, Ashland, OR, USA). We sorted mouse and human T cells with a FACS Aria II, FACS Aria III cell sorter (BD Biosciences) and an SH800 cell sorter (Sony, Tokyo, Japan).

In vitro and in vivo stimulation of $\mathbf{i T}_{\mathbf{S C M}}$ cells. For in vitro proliferation assay, naive $\mathrm{CD} 4{ }^{+} \mathrm{T}$ cells, $\mathrm{T}_{\mathrm{EM}}, \mathrm{T}_{\mathrm{CM}}$ cells, $\mathrm{iT}_{\mathrm{CM}}$ and $\mathrm{iT}_{\mathrm{SCM}}$ cells generated from in vitro activated Rag2 ${ }^{-1-}$ OT-II CD4 ${ }^{+}$T cells were CFSE labelled $\left(5 \times 10^{4}\right)$, then stimulated with $1.25 \times 10^{4}$ OVA-DCs for indicated periods. For in vivo proliferation assay, each $\mathrm{T}$ cell subset was obtained from $\mathrm{CD} 45.1^{+} \mathrm{CD} 4{ }^{+} \mathrm{OT}-\mathrm{II}$ mice. Naive $\mathrm{T}$ cells, $\mathrm{T}_{\mathrm{EM}}$ cells, $\mathrm{T}_{\mathrm{CM}}$ cells, $\mathrm{CD} 62 \mathrm{~L}^{+}$cells induced by $\mathrm{OP} 9$ coculture, $\mathrm{iT}_{\mathrm{CM}}$, and $\mathrm{iT}_{\mathrm{SCM}}$ cells $\left(2 \times 10^{5}\right)$ were transferred into $\mathrm{CD} 45.2^{+}$mice, followed by OVA/IFA immunization. T cells were analysed on day 3 or on day 6 .

Homoeostatic short and long-term survival assay. All $\mathrm{T}$ cells were prepared from Rag $2^{-1-}$ OT-II mice. For short term proliferation, we injected CFSElabelled $5 \times 10^{5} \mathrm{CD} 45.2^{+} \mathrm{T}$ cells into the sublethally irradiated recipient $\mathrm{CD} 45.1^{+}$congenic mice, then 20 days later, $\mathrm{T}$ cells were isolated from spleen and LNs and analysed. For long-term survival assay in vivo, CFSE-labelled $5 \times 10^{4}$ $\mathrm{CD} 45.2^{+} \mathrm{T}$ cells were adoptively transferred into sublethally irradiated $\mathrm{CD} 45.1^{+}$ congenic mice. After 150 days, numbers of the $\mathrm{CD} 45.2^{+} \mathrm{T}$ cells in the spleen, the peripheral lymph nodes (pLN), and the mesenteric LN (mLN) were determined. For serial transfer experiments, CFSE-labelled $1 \times 10^{6} \mathrm{CD} 45.2^{+} \mathrm{T}$ cells were injected into the sublethally irradiated recipient $\mathrm{CD} 45.1^{+}$congenic mice (first transfer), then 20 days later, $\mathrm{T}$ cells were isolated from spleen and LNs and CFSE ${ }^{\mathrm{lo}} \mathrm{CD} 44^{\mathrm{lo}} \mathrm{CD} 62 \mathrm{~L}^{\mathrm{hi}}$ fraction for $\mathrm{iT}_{\mathrm{SCM}}$ cells or naive $\mathrm{T}$ cells, or $\mathrm{CFSE}^{\mathrm{lo}} \mathrm{CD} 44^{\mathrm{hi}} \mathrm{CD} 62 \mathrm{~L} \mathrm{~L}^{\text {hi }}$ fraction for $\mathrm{iT}_{\mathrm{CM}}$ cells were sorted by FACS. These cells were then re-labelled with CFSE and transferred into the sublethally irradiated recipient mice (second transfer). Then 20 days later, the same procedure was performed as third transfer. Mice of third transfer were analysed on day 10 after transfer.

Adoptive transfer and tumour models. We intravenously injected isolated $\mathrm{T}$ cells into wild-type mice via the tail vein. Recipient mice were sublethally irradiated at $4.5 \mathrm{~Gy}$ before adoptive transfer. CD $45.2^{+} \mathrm{T}$ cells were transferred into $\mathrm{CD} 45.1^{+}$ congenic mice, while $\mathrm{CD} 45.1^{+}$congenically labelled $\mathrm{T}$ cells were transferred into CD45.2 ${ }^{+}$WT mice. For serial transfer experiments, CFSE-labelled CD ${ }^{+} \mathrm{T}$ cells were transferred into mice for the primary transfer. Twenty days later,

$\mathrm{CFSE}^{\mathrm{lo}} \mathrm{CD} 4{ }^{+} \mathrm{T}$ cells were sorted from the spleen and LNs of the primarily or secondarily transferred mice, and then transferred into the next-step mice.

The tumour transplantation and therapeutic model was performed according to the procedure reported by Gattinoni et al. ${ }^{12}$. E.G7-OVA $\left(1 \times 10^{7}\right)$ cells were intradermally injected eight days before $\mathrm{T}$ cell transfer to establish therapeutic models. T cells $\left(3 \times 10^{5}\right)$ were adoptively transferred into tumour-bearing mice in conjunction with emulsified incomplete Freund's adjuvant (IFA) containing OVA $(250 \mu \mathrm{g}$ per mouse). Mice were intraperitoneally injected with $500 \mathrm{ng}$ IL-2 twice, 24 and $48 \mathrm{~h}$ after OVA immunization. Tumour sizes were measured with a vernier caliper every 2-3 days, and tumour volume was calculated according to the following formula: volume $=0.5 \times$ length $\times$ width $^{2}$. We set a humane endpoint in the tumour model; mice were sacrificed when the tumour volume reached $2000 \mathrm{~mm}^{3}$, which has been approved by the Animal Ethics Committee of Keio University.

Side population analysis. Side population analysis was performed using a violet-excited DNA dye, Vybrant DyeCycle Violet Stain (DCV), as described previously ${ }^{35}$. Briefly, cells were incubated with a violet-excited dye, Vybrant DCV Stain, for $30 \mathrm{~min}$ at $37^{\circ} \mathrm{C}$ in the presence or absence of a ABCG2 inhibitor, FTC $(10 \mu \mathrm{M})$ in RPMI medium with $10 \%$ FBS. To inhibit DCV efflux in T cells, positive control samples were cultured with FTC.

CTL assay. LIVE/DEAD Viability/Cytotoxicity kits for mammalian cells containing calcein AM and ethidium homodimer-1(\#L3224) were obtained from Thermo Fisher Scientific. Isolated EBV-specific or Flu-specific CD8 ${ }^{+} \mathrm{T}$ cells were cocultured with autologous LCL in complete RPMI medium at $37^{\circ} \mathrm{C}$ for $3 \mathrm{~h}$. Collected cell suspension was stained with calcein AM and ethidium homodimer-1 (EthD-1) after incubation. Dead LCL cells were detected as CD8 $\alpha^{-}$calcein $\mathrm{AM}^{-}$EthD-1 ${ }^{+}$cells by flow cytometry analysis.

Microarray analysis. For mouse microarray analysis, total RNA was isolated using a ReliaPrep RNA Cell Miniprep System (\#Z6012, Promega, Madison, WI, USA). Microarray analysis was performed by TakaraBio using SurePrint G3 Mouse Gene Expression $8 \times 60 \mathrm{~K}$ (Agilent, Santa Clara, CA, USA). The expression values were calculated using Feature extraction software (Agilent Technologies). The values were normalized by adjusting each expression data to a 75 th percentile baseline, following $\log 2$ transformation. (The normalization step was performed with an original implementation of the 75th percentile normalization algorithm written in C.) Further statistical analyses were performed using the $\mathrm{R}$ statistical language and environment. The graphics generated and tools of analysis used are available at http://discover.nci.nih.gov. The data for mouse samples were deposited in GEO database (GSE 92381).

For the microarray analysis of human samples, all data, except the calculation of FKPM values of NexSeq data, were analysed by statistical computing, using the $\mathrm{R}$ language. The expression levels and expression barcodes of Affymetrix Human Gene 1.0 ST Array data (GSE23321, GSE68003 and GSE93211) were calculated from.CEL files using the 'frma' function of the frma package. The SRA files from Illumina NextSeq 500 (GSE80306) were converted to fastq files by a fastq-dump of the SRA toolkit and then mapped to an Ensemble GRCh37/hg19 genome annotation using STAR. FPKM values of uniquely mapped reads were calculated by Cufflinks. Before combining the ST array and NextSeq data, low or no expressed genes were removed by the following method: In the ST array, we selected 2496 genes which are estimated to be 'Gene Expression Barcode $=1$ ' by barcode function. In NextSeq, 8168 genes were selected by FKPM values $>2$. The expression levels of 1771 genes that overlapped in the ST array and NextSeq data were converted to $\log 2$, and the batch effects between the data set and platform were removed using the 'calcResiduals' function of the pcbcStats package.

Principal component analysis were performed by 'prcomp' function of stats package, respectively and visualized by ggplot 2 package. Clustering using cosine distance and the Ward's linkage method were performed using the 'Heatmap' function of the ComplexHeatmap package. Statistical tests between cell types were performed using the eBays function of the limma package. Then, 1600 genes among 7 cell types were selected by an FDR adjusted $P$ value $<0.01$. (GO component) pathway analysis of the selected genes was performed by Fisher's exact test using the 'fisher test' function of the stats package. The top 30 molecular concepts with $P$ values $<0.0001$ were visualized using the ComplexHeatmap package.

Quantitative real-time PCR. Total RNA was extracted using RNAiso Plus (\#Z6012, Takara Bio, Shiga, Japan) or ReliaPrep RNA Miniprep Systems (\#4368814, Promega) and subjected to reverse transcription using a High Capacity complementary DNA (cDNA) Synthesis Kit (Thermo Fisher Scientific). PCR analysis was performed using an iCycler iQ multicolour real-time PCR detection system (Bio-Rad, Hercules, CA, USA) and SsoFast EvaGreen Supermix (Bio-Rad). All primer sets yielded a single product of the correct size. Relative expression levels were normalized to Hprt. Specific primers are described in Supplementary Table 1.

Plasmid construction and retroviral transduction. Mouse Notch1 and Notch2 intracellular domain (ICD) were PCR-amplified from the mouse cDNA library and subcloned into eMIThyR vectors containing the MCS-IRES-Thyl.1 sequence. Retroviral transduction was performed, as described in ref. 36. Briefly, naive T cells were plated and subjected to the Th1-differentiation conditions described above starting on day 0. On Day 2, fresh retroviral supernatants were added, and the cells were centrifuged at 2,500 r.p.m. for $2 \mathrm{~h}$ at $35^{\circ} \mathrm{C}$. After spin infection, the cells were cultured in the appropriate Th cell differentiation media and collected on day 4 for OP9 coculturing. 
ELISA. For analysis of IL-2 in a cultured medium, the supernatants were analysed with a Mouse IL-2 ELISA Ready-SET-Go! (\#88-7024-77, eBioscience), according to the manufacturer's protocol.

Cell cycle and apoptosis detection assays. To detect cell cycle, cells were stimulated with anti-CD3 antibody $\left(5 \mu \mathrm{g} \mathrm{ml}^{-1}\right)$ and anti-CD28 antibody $\left(2 \mu \mathrm{g} \mathrm{ml}^{-1}\right)$ for zero, one, two and three days. Collected cells were suspended in ice-cold $90 \%$ methanol and incubated at $-30^{\circ} \mathrm{C}$ overnight for fixation and permeabilization. Fixed and permeabilized cells were re-suspended in propidium iodide (PI)-containing buffer and DNA content at indicated time points was analysed by flow cytometry. Cells in the G2/M phase, S phase and G0/G1 phase were detected as $\mathrm{PI}^{\text {high }}, \mathrm{PI}^{\text {int }}$ and $\mathrm{PI}^{\text {low }}$-stained cells, respectively.

To detect apoptosis, cells were stimulated with anti-CD3 antibody $\left(5 \mu \mathrm{g} \mathrm{ml}^{-1}\right)$ and anti-CD28 antibody $\left(2 \mu \mathrm{g} \mathrm{ml}^{-1}\right)$ for $60 \mathrm{~h}$. Apoptotic cells were stained by AnnexinV-FITC Apoptosis kit (BioVision) and analysed by flow cytometry.

Study approval. This study was approved by the Institutional Review Board of Keio University School of Medicine (Approval number: 20120039), and conducted in compliance with the Declaration of Helsinki. Written informed consent was obtained from all individuals.

Statistics. Statistical analysis was performed using the two-tailed unpaired Student's $t$-test, Mann-Whitney test, one-way ANOVA, two-way ANOVA and Kaplan-Meier method, using GraphPad Prism version 6.05 software (GraphPad Software, CA, USA). One-way ANOVA and two-way ANOVA were used for multiple comparisons. The variance among the groups was estimated using the F-test, and $P$ values $<0.05$ were considered statistically significant. All data are presented as the mean \pm s.e.m. Mice were randomly assigned to experimental groups. The investigators were not blinded to allocation during experiments and outcome assessment.

Data availability. The data that support the findings of this study are available within supplementary information files or from the corresponding author on reasonable request. Microarray data that support the findings of this study have been deposited in GEO with the primary accession codes GSE92381 (mouse) and GSE93211 (human)

\section{References}

1. June, C. H. Adoptive T cell therapy for cancer in the clinic. J. Clin. Invest. 117, 1466-1476 (2007).

2. Klebanoff, C. A., Acquavella, N., Yu, Z. \& Restifo, N. P. Therapeutic cancer vaccines: are we there yet? Immunol. Rev. 239, 27-44 (2011).

3. Jiang, Y., Li, Y. \& Zhu, B. T-cell exhaustion in the tumor microenvironment. Cell Death Dis. 6, e1792 (2015).

4. Gattinoni, L. et al. Acquisition of full effector function in vitro paradoxically impairs the in vivo antitumor efficacy of adoptively transferred CD8 $+\mathrm{T}$ cells. J. Clin. Invest. 115, 1616-1626 (2005).

5. Nishimura, T. et al. Generation of rejuvenated antigen-specific $\mathrm{T}$ cells by reprogramming to pluripotency and redifferentiation. Cell Stem Cell 12, 114-126 (2013).

6. Vizcardo, R. et al. Regeneration of human tumor antigen-specific $\mathrm{T}$ cells from iPSCs derived from mature CD8 + T cells. Cell Stem Cell 12, 31-36 (2013).

7. Mueller, S. N., Gebhardt, T., Carbone, F. R. \& Heath, W. R. Memory T cell subsets, migration patterns, and tissue residence. Annu. Rev. Immunol. 31, 137-161 (2013).

8. Hinrichs, C. S. et al. Human effector CD8 $+\mathrm{T}$ cells derived from naive rather than memory subsets possess superior traits for adoptive immunotherapy. Blood 117, 808-814 (2011).

9. Maecker, H. T., McCoy, J. P. \& Nussenblatt, R. Standardizing immunophenotyping for the human immunology project. Nat. Rev. Immunol. 12, 191-200 (2012).

10. Gattinoni, L. et al. A human memory T cell subset with stem cell-like properties. Nat. Med. 17, 1290-1297 (2011).

11. Pulko, V. et al. Human memory T cells with a naive phenotype accumulate with aging and respond to persistent viruses. Nat. Immunol. 17, 966-975 (2016).

12. Gattinoni, L. et al. Wnt signaling arrests effector T cell differentiation and generates CD8 + memory stem cells. Nat. Med. 15, 808-813 (2009).

13. Gattinoni, L., Ji, Y. \& Restifo, N. P. Wnt/ $\beta$-catenin signaling in T-cell immunity and cancer immunotherapy. Clin. Cancer Res. 16, 4695-4701 (2010).

14. Lugli, E. et al. Identification, isolation and in vitro expansion of human and nonhuman primate T stem cell memory cells. Nat. Protoc. 8, 33-42 (2013).

15. Amsen, D. et al. Instruction of distinct CD4 T helper cell fates by different notch ligands on antigen-presenting cells. Cell 117, 515-526 (2004).
16. Laky, K., Evans, S., Perez-Diez, A. \& Fowlkes, B. J. Notch signaling regulates antigen sensitivity of naive $\mathrm{CD} 4+\mathrm{T}$ cells by tuning co-stimulation. Immunity 42, 80-94 (2015).

17. Amsen, D., Antov, A. \& Flavell, R. A. The different faces of Notch in T-helper-cell differentiation. Nat. Rev. Immunol. 9, 116-124 (2009).

18. Maekawa, Y. et al. Notch controls the survival of memory CD4 $+\mathrm{T}$ cells by regulating glucose uptake. Nat. Med. 21, 55-61 (2015).

19. Zhou, S. et al. The ABC transporter Bcrp1/ABCG2 is expressed in a wide variety of stem cells and is a molecular determinant of the side-population phenotype. Nat. Med. 7, 1028-1034 (2001).

20. Kruse, J.-P. \& Gu, W. Modes of p53 regulation. Cell 137, 609-622 (2009)

21. Dotto, G. P. Crosstalk of Notch with p53 and p63 in cancer growth control. Nat. Rev. Cancer 9, 587-595 (2009).

22. Beverly, L. J., Felsher, D. W. \& Capobianco, A. J. Suppression of p53 by notch in lymphomagenesis: implications for initiation and regression. Cancer Res. 65, 7159-7168 (2005).

23. Watanabe, M., Moon, K. D., Vacchio, M. S., Hathcock, K. S. \& Hodes, R. J. Downmodulation of tumor suppressor p53 by $\mathrm{T}$ cell receptor signaling is critical for antigen-specific CD4 $+\mathrm{T}$ cell responses. Immunity 40, 681-691 (2014).

24. Sabatino, M. et al. Generation of clinical-grade CD19-specific CAR-modified CD8 + memory stem cells for the treatment of human B-cell malignancies. Blood 128, 519-528 (2016).

25. Kubuschok, B. et al. Use of spontaneous Epstein-Barr virus-lymphoblastoid cell lines genetically modified to express tumor antigen as cancer vaccines: mutated p21 ras oncogene in pancreatic carcinoma as a model. Hum. Gene Ther. 13, 815-827 (2002)

26. Hui-Yuen, J., McAllister, S., Koganti, S., Hill, E. \& Bhaduri-McIntosh, S. Establishment of Epstein-Barr virus growth-transformed lymphoblastoid cell lines. J. Vis. Exp. e3321, doi:10.3791/3321 (2011).

27. Backer, R. A. et al. A central role for Notch in effector CD8 $+\mathrm{T}$ cell differentiation. Nat. Immunol. 15, 1143-1151 (2014).

28. Kryczek, I. et al. Human TH17 cells are long-lived effector memory cells. Sci. Transl. Med. 3, 104ra100 (2011).

29. Palomero, T., Dominguez, M. \& Ferrando, A. A. The role of the PTEN/AKT Pathway in NOTCH1-induced leukemia. Cell Cycle 7, 965-970 (2008).

30. Chen, L. \& Han, X. Anti-PD-1/PD-L1 therapy of human cancer: past, present, and future. J. Clin. Invest. 125, 3384-3391 (2015).

31. Ohaegbulam, K. C., Assal, A., Lazar-Molnar, E., Yao, Y. \& Zang, X. Human cancer immunotherapy with antibodies to the PD-1 and PD-L1 pathway. Trends Mol. Med. 21, 24-33 (2015).

32. Buchbinder, E. \& Hodi, F. S. Cytotoxic T lymphocyte antigen-4 and immune checkpoint blockade. J. Clin. Invest. 125, 3377-3383 (2015).

33. Norell, H. et al. Inhibition of superoxide generation upon T-cell receptor engagement rescues mart-1 27-35-reactive $\mathrm{T}$ cells from activation-induced cell death. Cancer Res. 69, 6282-6289 (2009).

34. Banerjee, A. et al. Lack of p53 augments antitumor functions in cytolytic T Cells. Cancer Res. 76, 5229-5240 (2016).

35. Hogquist, W. A. et al. T cell receptor antagonist peptides induce positive selection. Cell 76, 17-27 (1994).

36. Barnden, M. J., Allison, J., Heath, W. R. \& Carbone, F. R. Defective TCR expression in transgenic mice constructed using cDNA-based alpha- and bold beta-chain genes under the control of heterologous regulatory elements. Immunol Cell Biol. 76, 34-40 (1998).

37. Shinkai, Y. et al. RAG-2-deficient mice lack mature lymphocytes owing to inability to initiate V(D)J rearrangement. Cell 68, 855-867 (1992).

38. Telford, W. G., Bradford, J., Godfrey, W., Robey, R. W. \& Bates, S. E. Side population analysis using a violet-excited cell-permeable DNA binding dye. Stem Cells 25, 1029-1036 (2007).

39. Sekiya, T. et al. Nr4a receptors are essential for thymic regulatory $\mathrm{T}$ cell development and immune homeostasis. Nat. Immunol. 14, 230-237 (2013).

\section{Acknowledgements}

We thank Mayako Asakawa (Keio University) for preparing the virus stock; Minako Ito, Noriko Shiino, Yoshiko Noguchi, Yasuko Hirata and Yukiko Tokifuji (Keio University) for their technical assistance; Yuki Ushijima (Keio University) for manuscript preparation; Kazuhiko Takahara (Kyoto University) and Ryusuke Muro (The University of Tokyo) for providing materials; Taeka Hayakawa, Hajime Kamijuku, Tomonori Yaguchi and Yutaka Kawakami (Keio University) for discussions; and the NIH Tetramer Facility for reagent preparation. OP9 cells and OP9-DL1 cells were kindly provided by Hiroshi Kawamoto (Kyoto University). This work was supported by special Grants-inAid from the Ministry of Education, Culture, Sports, Science and Technology of Japan (No. 25221305), Advanced Research \& Development Programs for Medical Innovation (AMED-CREST), the Takeda Science Foundation, the Uehara Memorial Foundation, the Mochida Memorial Foundation for Medical and Pharmaceutical Research, the Kanae 
Foundation, the SENSHIN Medical Research Foundation and the Keio Gijuku Academic Developmental Funds.

\section{Author contributions}

T.K. and R.M. performed experiments; T.K., M.K. and Y.O. analysed data; Y.K., T.S.,

S.C., K.K., M.K., T.S., H.N. and T.M. edited the manuscript; R.M. and A.Y. supervised the research; and T.K., R.M. and A.Y. wrote the manuscript.

\section{Additional information}

Supplementary Information accompanies this paper at http://www.nature.com/ naturecommunications

Competing interests: The authors declare no competing financial interests.

Reprints and permission information is available online at http://npg.nature.com/ reprintsandpermissions/
How to cite this article: Kondo, T. et al. Notch-mediated conversion of activated T cells into stem cell memory-like T cells for adoptive immunotherapy. Nat. Commun. 8, 15338 doi: $10.1038 /$ ncomms15338 (2017).

Publisher's note: Springer Nature remains neutral with regard to jurisdictional claims in published maps and institutional affiliations.

(c) (i) This work is licensed under a Creative Commons Attribution 4.0 International License. The images or other third party material in this article are included in the article's Creative Commons license, unless indicated otherwise in the credit line; if the material is not included under the Creative Commons license, users will need to obtain permission from the license holder to reproduce the material. To view a copy of this license, visit http://creativecommons.org/licenses/by/4.0/

(C) The Author(s) 2017 